University at Buffalo School of Law

Digital Commons @ University at Buffalo School of Law

4-1-1990

\title{
The Constitutional Catechism of Antonin Scalia
}

George Kannar

University at Buffalo School of Law

Follow this and additional works at: https://digitalcommons.law.buffalo.edu/journal_articles

Part of the Judges Commons, and the Supreme Court of the United States Commons

\section{Recommended Citation}

George Kannar, The Constitutional Catechism of Antonin Scalia, 99 Yale L.J. 1297 (1990).

Available at: https://digitalcommons.law.buffalo.edu/journal_articles/904

\section{C. ${ }_{\text {COPYRIGHT }}^{\text {N }}$}

This Article is brought to you for free and open access by the Faculty Scholarship at Digital Commons @ University at Buffalo School of Law. It has been accepted for inclusion in Journal Articles by an authorized administrator of Digital Commons @ University at Buffalo School of Law. For more information, please contact lawscholar@buffalo.edu. 


\title{
Comment
}

\section{The Constitutional Catechism of Antonin Scalia}

\author{
George Kannarf
}

Split personalities have twice as many problems, and constitutional scholarship has been showing signs of schizophrenia for quite a while. Since the early 1970's, an ever-growing set of scholars has been launching grand new theories, which seem always to conclude by supporting those scholars' own values. Others meanwhile pick apart particular cases and doctrinal areas, to show how this opinion or the other "proves" that some poor Justice's theory "ultimately" does not work. And Critical Legal Scholars have now complicated matters even further, by deploying their own impressive talents to proving that no one's theory does. ${ }^{\text {I }}$

Yet the Court still continues to decide its cases, and the approaches different justices adopt continue to matter greatly, however imperfect those approaches may be. ${ }^{2}$ And of course the more imperfect the theory is, the

$†$ Associate Professor, SUNY-Buffalo School of Law. Thanks are owed to Dawn Baksh, Wade J. Newhouse, and Robert Steinfeld, and especially to Guyora Binder, David B. Filvaroff, Fred Konefsky, Aviam Soifer, and (even more especially) Ellen V. Weissman. Research assistance was provided by Jonathan G. Hager and Margot L. Watt. I am particularly grateful to Mrs. Roma Konefsky for her creative sleuthing in the environs of Brooklyn College. This effort is dedicated to the memory of Jack D. Novik, National Staff Counsel of the ACLU.

1. M. Tushnet, Red, White, and Blue: A CRitical Analysis of Constitutional Law (1988) (exasperated Critical scholar, after demolishing every possible viewpoint, declares "critique is all there is").

2. See generally Carter, Constitutional Adjudication and the Indeterminate Text: A Preliminary Defense of An Imperfect Muddle, 94 YALE L.J. 821 (1985) (suggesting that in view of such inevitable imperfection, theorists should concentrate their efforts on shoring up general structural role of Supreme Court as interpreter and policy-maker, instead of trying too hard to justify details of particular interpretive norms). 
more it matters who is applying it. When Antonin Scalia was nominated to be an associate justice in 1986, however, neither the Senate Judiciary Committee nor the full Senate much bestirred themselves to inquire beyond his general reputation as a highly intelligent conservative before voting unanimously to confirm him, ${ }^{3}$ and the 1982 hearings on his nomination to the D.C. Circuit are almost comical in their brevity. ${ }^{4}$ For the most part, examinations of Scalia's record, by scholars and by the interest groups involved in the confirmation process, have so far been confined to summarizing his judicial work product or his views on specific doctrinal subjects, focusing largely upon the results that he has endorsed or reached..$^{5}$ But since the Justice is likely to be with us for a very long time, it is a concern of some importance to examine the sources, as well as the results of his approach to the judicial task. Doing so has become considerably more feasible since Scalia joined the Court, for it is only since his appointment ${ }^{6}$ that he has attempted to articulate a comprehensive constitutional world view. Because he has done so in terms that are both unusually specific and unusually self-revelatory, it now becomes possible to explore his constitutional identity in the context of his personal one, to consider what he thinks in the context of who he is.

3. S. Exec. Rep. No. 19, 99th Cong., 2d Sess. (1986); 132 Cong. Rec. S12,779 (1986).

4. The "hearings" on Scalia's D.C. Circuit nomination consume a total of two and one-half pages, and consist entirely of extremely soft questions from then-Judiciary Committee Chair, Sen. Strom Thurmond. Confirmation of Federal Judges, Hearings Before the Senate Comm. on the Judician', 97th Cong., 2d Sess. 90 (1982) [hereinafter 1982 Hearings].

5. See King, Justice Antonin Scalia: The First Term on the Supreme Court, 1986-1987, 20 Rutgers L.J. 1 (1987); Scatena, Deference to Discretion: Scalia's Impact on Judicial Revieut of Agency Action in an Era of Deregulation, 38 Hastings L.J. 1223 (1987); Wilson, Justice Diffused: A Comparison of Edmund Burke's Conservatism with the Vieus of Fiz'e Conservativ' Academic Judges, 40 U. Mrami L. Rev. 913 (1986); Wilson, Constraints of Pouter: The Constitutional Opinions of Judges Scalia, Bork, Posner, Easterbrook and Winter, 40 U. Miami L. Rev. 1171 (1986) [hereinafter Wilson, Constraints of Pouter]; Note, The Establishment Clause and Justice Scalia. What the Future Holds for Church and State, 63 Notre DAME L. Rev. 380 (1988); Comment, Justice Scalia and Judicial Restraint: A Conservatize Resolution of Conflict Betueen Individual and State, 62 Tul. L. REv. 225 (1987) [hereinafter Comment, Judicial Restraint]; Comment, The Appellate Jurisprudence of Justice Antonin Scalia, 54 U. CHI. L. REv. 705 (1987). This is not intended to diminish or shortchange in any way the work of those who have previously studied Justice Scalia's record. Given a subject of such prominence, importance and long-standing public visibility, one hardly begins an inquiry such as this on a blank slate. Not surprisingly, therefore, a number of the themes set forth herein have previously been noted. In his review of Justice Scalia's first term, for example, King has commented upon Scalia's respect for precedent and tendency to exclude his personal views from his jurisprudence. King, supra, at 77. One study has traced Scalia's hostility to judicial "policy" analysis (as well as his general judicial philosophy) during the time preceding his Supreme Court appointment. Note, supra, at 385-88. Wilson has traced Scalia's use of history and text in his D.C. Circuit work. Wilson, Constraints of Pou'er, supra, at 1192. Wilson has also noted that because Scalia functions at a relatively concrete level, he may be more acceptable to liberals than other, more ideological-sounding conservatives, even if some of his individual opinions also contain particularly inflammatory language. A student commentator has noted Scalia's tendency to disappoint conservatives in his criminal procedure decisions. Comment, Justice Scalia and Judicial Restraint, supra, at 226 \& n.11. The views of Scalia's interest group opponents are set forth at length in Hearings on the Nomination of Judge Antonin Scalia Before the Senate Comm. on the Judiciary, 99th Cong., 2d Sess. (1986) [hereinafter 1986 Hearings].

6. See Wilson, Constraints of Power, supra note 5, at 1172 (Scalia had not previously articulated any grand theory). 
Embarking on such a task is of course to enroll within a wellestablished tradition. But while most previous analyses of the approaches to constitutional adjudication adopted by newly-appointed Justices have tended to revolve around the Justice's-or the theorist's-social and political outlook, ${ }^{7}$ such political analysis is not the purpose here. The present focus will be on Scalia's technique, not his conservative political views or his concededly conservative judicial record. Indeed, in political terms, this Article concentrates upon unrepresentative Scalia decisions, cases in which the Justice has upset ordinary political expectations by reaching "liberal" conclusions. Yet this "man bites dog" theme is a crucial element of the Scalia story: for all his strongly-held views, Justice Scalia nonetheless still seems to be a person driven by his methodological commitments rather than a desire to reach particular results. For Justice Scalia, more than for most other constitutional thinkers, a priori interpretive commitments tend to lead to unexpected outcomes.

These increasingly apparent contradictions between Justice Scalia's well-known political philosophy and his votes in particular cases have begun to earn him a reputation for being somewhat enigmatic. ${ }^{8}$ In fact, however, he is anything but. $\mathrm{He}$ is not the slightest bit reticent about saying exactly what he means, on the bench or off. Listening carefully to what he says reveals him to be an emblematic, rather than an enigmatic figure, someone who is interesting and important for what he embodies personally as well as for the office that he holds. Whatever he may represent politically, Justice Scalia is also an individual in whom constitutional theory and personal identity fuse-an integrated constitutional personality in a deconstructed, schizophrenic, and generally post-modernist age. His Supreme Court performance therefore presents fundamental issues of constitutional theory and interpretation in a uniquely concrete set-

7. The justly celebrated analyses of the early Justice Rehnquist, see Shapiro, Mr. Justice Rehnquist: A Preliminary View, 90 Harv. L. Rev. 293 (1976), and Justice O'Connor, see Sherry, Civic Virlue and the Feminine Voice in Constitutional Adjudication, 72 U. VA. L. REv. 543 (1986), would seem to conform, despite Sherry's strong additional emphasis on O'Connor's "feminine voice." It is hard to see how one could choose anything other than a political approach, or come to anything other than political conclusions, when dealing with such an ideologue as William Rehnquist. On the other hand, proving that Justice O'Connor's "emphasis on contextual decision-making . . . and the virtues of the decisionmaker" really has to do with "a characteristically feminine perspective," $i d$. at 604-05, would seem a somewhat harder case to make. For one thing, such a world view might as easily have been derived from O'Connor's experience as a state legislator as from her gender. For another, context-specific "balancing" and deference to other professional decisionmakers characterize a grcat deal of modern constitutional adjudication. See generally Aleinikoff, Constitutional Law in the Age of Balancing, 96 YALE L.J. 943 (1987) ("balancing" vocabulary has long been dominant).

8. See, e.g., Yoder, Tring to Figure Out Scalia, Wash. Post, Aug. 1, 1989, at A21, col. 6 (columnist befuddled by Scalia's voting record). These "contradictions" appear, moreover, even in subjectmatter areas where all concerned believed Scalia's views to be firm and long-established. Compare John Doe Agency v. John Doe Corp., 110 S. Ct. 471, 479 (1989) (Scalia, J., dissenting) (Scalia would require disclosure of agency records under Freedom of Information Act (FOIA), despite antiFOIA reputation) with 1986 Hearings, supra note 5, at 256-58 (testimony of Audrey Feinberg concerning Scalia's strong pro-secrecy record on D.C. Circuit) and 1982 Hearings, supra note 4, at 90-92 (Scalia testifies about evils of 1974 Freedom of Information Act amendments). 
ting-where theory is in practice, and where both are in a life. Reviewing his performance thus presents a rare opportunity for examining the connections between personal background, political ideology, and constitutional method. This Article will examine the theory, sources, and results of Justice Scalia's constitutional methodology to aid in understanding him, but it will also consider and assess him as the emblematic figure that he is.

The first section focuses upon Justice Scalia's constitutional perspective and the route by which he came to it. Part I.A will examine his explicitly theoretical statements concerning constitutional adjudication, which articulate an exceptionally clear constitutional vision that is at once rigid and pragmatic. Part I.B will explore the sources of Scalia's approach to adjudication in his personal background. The hypothesis will be that, as a preVatican II Roman Catholic, Scalia absorbed very early a particular formalistic vision of how one perceives and evaluates the world, as well as a particular literalistic view of what one does with texts. Moreover, by virtue of being an American Catholic interested in public affairs, Scalia also faced certain culturally-complicated pressures as he sought to accommodate his personal moral views with his worldly participation, a conflict whose pragmatic resolution both drew upon and influenced his larger sense of the relationship between legal form and legal substance.

Part II will examine the implications of Justice Scalia's methodological commitments in the context of a particular doctrinal field-constitutional criminal procedure. A selection of Justice Scalia's criminal procedure opinions will be reviewed-to examine the strengths, weaknesses, and limitations of a systematically "conservative" approach in terms of its internal coherence and its substantive results. The cases in this section are organized under two headings: those in which Scalia was able to follow his literalist and formalist impulses without indulging in any form of "balancing" or policy analysis, and those in which the same impulses served to confine and limit the use of balancing analysis where use of it was inescapable. In both types of cases, the individual and emblematic Antonin Scalia both shine through: the willing servant of a particular culturally-induced interpretive world view, and the carrier of lessons about what it means to approach the unruly world of constitutional adjudication as though it were amenable to such theoretical control. Part III will explore the meaning of these lessons for those whose politics differ from Justice Scalia's.

The choice of criminal procedure for the subject of this exercise is not casual. For one thing, prior to his appointment to the Court, criminal procedure was largely unexplored territory for Scalia. It is therefore a constitutional arena in which his effort to work out the implications of his methodology is very much ongoing, and linked to his first principles in a particularly direct and unmediated way. Second, criminal procedure is an 
area of the law that mainstream scholars have traditionally neglected at the level of constitutional theory. ${ }^{9}$ Because Scalia's deep theoretical commitments prevent him from distinguishing between criminal procedure and other constitutional cases (and because, as a Justice rather than a theorist, he cannot just ignore them), his criminal procedure record presents the question whether seeking a comprehensive constitutional theory is a sensible scholarly objective in a context not frequently examined. Third, because criminal procedure is an area in which many Americans seem to hold exceptionally clear beliefs regarding what counts as a "conservative" or "liberal" outcome, in this area the ironic political implications of Justice Scalia's conservative methodology are particularly well spotlighted.

Finally, the recent history of criminal procedure adjudication is another important factor in this choice. ${ }^{10}$ Over the past twenty years, the Burger Court effectively reversed the public vocabularies ordinarily associated with political "liberalism" and political "conservativism" in its criminal procedure cases. In criminal procedure cases, the Burger Court's liberals tended to harken to ageless principles and values, as they saw Warren Court results unravel. The Court's conservatives came to be the faction that most clearly saw itself as adapting its decisions to contemporary society's perceived demands, openly using the Court's power to accommodate and "balance" concerns of law enforcement "policy."11

9. See Schauer, Easy Cases, 58 S. Cal. L. Rev. 399, 400 n.4 (1985) (noting this deficiency); Wasserstrom \& Seidman, The Fourth Amendment as Constitutional Theory, 77 GEO. L.J. 19 (1988) (same).

10. The recent history of criminal procedure doctrine has inspired hundreds, perhaps thousands of articles, many of which make similar observations. For some samples, see The Burger Years: Rights AND Wrongs in The Supreme Court, 1969-1986, at 143-88 (H. Schwartz ed. 1987); Whitebread, The Burger Courl's Counter-Revolution in Criminal Procedure: The Recent Criminal Ditcistons of the United States Supreme Court, 24 WashbuRN L.J. 471 (1985) (Burger Court proprosecution and devoted to case-by-case decision-making based upon perception of crime control needs and immediate factual circumstances, rather than legal principles or operational rules).

11. As used in the text, "policy" is meant to be a shorthand for what others have described as a "balancing" approach to adjudication, which is what Scalia seems determined to resist. See generally Aleinikoff, supra note 7. The use of the term "principle" is similarly meant only to invoke the general notion of a non-balancing methodology, not to implicate every detail of anyone's more complete theory using the same word. E.g., R. Dworkin, TAking Rights Seriously (1977) (theory of how courts decide based upon "principle").

To say that the Burger Court invoked "policy" in its criminal procedure decisions is not, of course, to suggest that what the Burger Court did made any sense whatsoever, even from a narrow law enforcement "policy" perspective. Many commentators at both ends of the political spectrum have long noted that the result of the Burger Court's ad hoc concern for increasing "toughness" against criminals has been to create a confusing hodge-podge in contemporary criminal procedure doctrine-not the elimination of Warren Court rules, but the creation of a complex system of rules and counter-rules, of principles with "exceptions," of exceptions with exceptions. Though some have characterized the recent era in criminal procedure as representing a triumph of the vision of criminal procedure as a "system of rules," S. WALKER, The RULE ReVolution: ReFlections ON THE Transformation of American Criminal Justice, 1950-1988 (Institute for Legal Studies, Working Papers, Series 3, 1988), it would be more accurate to say that what we have is all rules and no system.

Moreover, the Burger Court's perception of law enforcement's needs was entirely illusory; the evidence is clear that there is no serious relationship between constitutional protections and controlling 
During his first three terms on the Court, Justice Scalia has consistently shown signs of rejecting this "conservative" policy analysis, and his primary reasons for doing so do not appear to be based upon a libertarian regard for "criminal" rights per se. Rather, it is the basic constitutional methodology he has adopted-combining respect for stare decisis with a "restrained" interpretation of precedent and the Constitution's text-which so frequently, and almost automatically, takes him to the defendant's side. Precisely because Scalia's formalist method is so stereotypically "conservative"-so classically Frankfurterian in its structural assumptions, so sacerdotal in its conception of the judge's role ${ }^{12}$-it may, as a practical matter, also tend to help legitimate outcomes that would otherwise be more controversial with "law and order" politicians, who show few signs of disappearing from the scene.

But if such "conservative" methodological values, rigorously applied, do not always produce socially "conservative" results, is it possible that they have been dismissed prematurely by putatively progressive scholars? Other constitutional theorists may not share the cultural commitments that give meaning to Justice Scalia's adjudicative practice. But to the extent that Scalia's internally rational system resonates with the wider culture in which lawyers work and law is made, more room may need to be made for it at the scholars' table. The fusion of constitutional theory and cultural identity in Antonin Scalia should prompt scholars to consider whether they are any less culturally limited in the construction of their own views. They may well conclude, upon such self-reflection, that the time has come to redefine the goals toward which their scholarship is directed: to worry less about developing their own exotic vocabularies, and more about the Supreme Court that we have.

Considered emblematically, Justice Scalia's life and record call into question all efforts to construct comprehensive abstract systems of constitutional thought. They also suggest that an academic culture which so consistently tends to produce such systems may itself need to be transcended.

crime. See D. Bazelon, Questioning Authority: Justice and Criminal Law (1988). Recent examinations of the severe problems besetting the contemporary criminal justice system have shown that such "law and order" arguments are becoming even more irrelevant as time goes on. Arresting criminals is not currently a problem. The problem is efficiently processing the huge number of persons apprehended through our severely overloaded criminal courts and finding room for those convicted in our severely limited prison space. Cf. Why Justice Can't Be Done, Newswerk, May 29, 1989, at 36-37 (reporting observations of experts and police chiefs). Resource constraints, not constitutional ones, are really responsible for public perceptions of a "weak" or "soft" criminal justice system.

12. "I don't deal with policy, that's not my business. I gave it up when I took the veil." Scalia at BC: Conservatiz' Justice Drau's Fire After Speech, The Kingsman (Brooklyn College student newspaper), Oct. 23, 1989, at 1 (quoting Justice Scalia). 


\section{The Social Gonstruction of a Constitutional Perspective}

\section{A. "Practical Originalism"}

As John Hart Ely noted long ago, ${ }^{13}$ for most people trained as lawyers, the doctrine of "original intent" is not without some degree of purely intellectual appeal, its apparent lack of historical grounding notwithstanding. It only stands to reason, if statutes are to be construed in accordance with legislators' intentions, that the most fundamental "statute"- the Supreme "Law" of the Land-should be construed in a similar fashion. Considering who appointed him, it is not surprising that Justice Scalia has declared himself an "originalist," one who sees constitutional adjudication as "a process that resembles ordinary statutory construction"14 in which "the task at hand is not to determine what seems like good policy at the present time, but to ascertain the meaning of the text." 15 Yet, unlike many who share this narrow view of constitutional adjudication, Scalia's adherence to originalism represents a pragmatic choice, not a true article of faith, or even a genuine leap of it. It is an originalism grounded in, of all things, a sense of practicality and realism, a self-conscious selection of what the hermeneuticians call a "convention,"16 a canon for structuring the interpretive process adopted for reasons John Dewey would have appreciated and understood.

As Scalia has elaborated his views since ascending to the bench, the prime attraction of the originalist convention is that it is coherent, even if it is often merely a coherent fiction. "[O]riginalism is not, and had perhaps never been, the sole method of constitutional exegesis,"17 Scalia has said with a tone of Realism. By and large, constitutional opinions are "rendered not on the basis of what the Constitution originally meant, but on the basis of what the judges currently thought it desirable for it to mean." ${ }^{18}$ To Scalia's ironic eye, the modern innovation involves an over-

13. J. Ely, Democracy and Distrust 12 (1980).

14. Address by Justice Antonin Scalia, Remarks at the 24th Australian Legal Convention 12 (Sept. 21, 1987).

15. Id. Consequently, Scalia has been skeptical, to put it mildly, of attempts to determine the meaning of statutes from sources other than statutory text. See Edwards v. Aguillard, 482 U.S. 578, 610 (1987) (Scalia, J., dissenting). Indeed, his standard bar group "stump speech," called "Legislative History," asserts that courts' use of such histories is a "legalistic arms race" in which differing judges select out whatever will be useful to their cause. A. Scalia, Legislative History 5 (copy on file with author); see alsa Scalia, Originalism: The Lesser Evil, 57 U. CIN. L. REv. 849, 854 (1989) (Constitution is "an enactment that has a fixed meaning ascertainable through the usual devices familiar to those learned in the law") [hereinafter Scalia, Originalism]. Although Scalia's approach to this issue in some ways resembles Leo Strauss' approach to political and social theory, see Wood, The Fundamentalists and the Constitution, N.Y. Rev. Books, Feb. 18, 1988, at 33, not every former University of Chicago law professor currently on the bench accepts such views, by any means. See Posner, What Am I? A Potted Plant?, New Republuc, Sept. 28, 1987, at 23-25 (attacking Walter Berns for making judging seem too mechanical).

16. Sep S. Mailloux, Interpretive Conventions (1982).

17. Scalia, Originalism, supra note 15 , at 852 .

18. Id. 
dose of intellectual integrity: "[I]n the past, nonoriginalist opinions have almost always had the decency to lie, or at least to dissemble, about what they were doing."19 Recently, however, liberal scholars and Justices seem increasingly to have abandoned the venerable charade, according to Scalia, and have thereby created political problems for themselves because of their subsequent inability to present a united front concerning what to put in originalism's place. Originalism therefore prospers, or at least survives, because the truth is, "You can't beat somebody with nobody."

Moreover, as he sees it, most of the non-originalist "nobodies" that have been proposed also work out worse in practice. While Scalia admits that originalism is "not without its warts,"21 he also believes that the recently articulated alternative approaches to constitutional interpretation have even bigger ones. The most troubling, not surprisingly, is their unconfinability. Citing the fact that "modern" constitutional decisions have radically altered long-standing conceptions of the rights of property as an illustration, he believes that "we should not fool ourselves into believing"22 that departures from "strict" readings of the "original" constitutional document do not have negative as well as positive implications for the general scope of human liberty: "Nonoriginalism . . . is a two-way street that handles traffic both to and from individual rights." ${ }^{23}$ For Scalia, originalism represents the lesser of two evils because it reduces the chances "that the judges will mistake their own predilections for the law," which he, like many others, regards as the major danger for unelected, life-tenured Justices to avoid. ${ }^{24}$ Having a settled convention at least has the advantage of establishing some relatively objective limits on what the Justices may do.

Unlike other conservatives, however, for a variety of reasons Scalia does not see an "undiluted"25 originalism as being realistic or viable either. In the real world, the dispute over constitutional methodology is not between polar opponents who can be neatly labelled as originalists and nonoriginalists. As he sees it, the real dispute is much more practical. As a matter of practical reality, he says, even professed originalists ultimately concede the need for some evolution. The serious question has to do with differences of opinion "concerning the nature and degree of evidence necessary to demonstrate that constitutional evolution has occurred."26 In the end, Scalia finds himself to be a "faint-hearted" brand of originalist. ${ }^{27}$

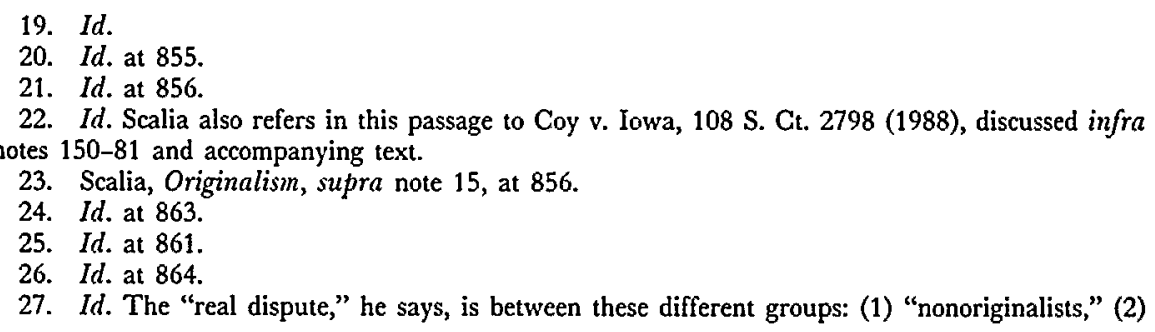


One reason Scalia's loyalty to originalism is "faint-hearted" arises from his decided skepticism toward what are generally taken to be the standard conservative historiographical claims concerning "original intent." ${ }^{28} \mathrm{Al}-$ though in practice he bows to the usual historicist "originalist" convention in a number of his opinions, at its "faint" heart Scalia's own version of originalism is not ultimately based upon historicism; his preference is for a philological, rather than historical, approach. No doubt to the dismay of deconstructionists and hermeneuticians everywhere, Scalia does not "agree with, or even take very seriously, the intricately elaborated scholarly criticisms to the effect that . . . words have no meaning." ${ }^{29}$ For purposes of day-to-day judging, "[t]hey have meaning enough." 30 Therefore, to the conscientious "faint-hearted" judge, it matters a great deal what the Constitution says.

Still, to say that "words have meaning" is not, for Scalia, to terminate the inquiry; one must still determine what the meaning of the Constitution's words is. History in the usual originalist sense is little, if any, help. As Scalia notes with considerable candor, the Justices' crowded "timechart" alone makes serious devotion to the historiographic leg-work necessary for arriving at such determinations in a reliable manner logistically daunting, if not impossible. ${ }^{31}$ Fortunately, according to Scalia, there is

\footnotetext{
"faint-hearted originalists;" and (3) "pure-originalists-accepting-for-the-sake-of-argumentevolutionary-content" over how to determine whether "evolution" has occurred. Id. Scalia's official position is that "evolution" is limited to "current social practice as reflected in extant legislation," Scalia, The Rule of Law" as a Law of Rules, 56 U. CHI. L. REv. 1175, 1185 (1989) (hereinafter Scalia, Rult of Law ]; sep also Stanford v. Kentucky, 109 S. Ct. 2969 (1989) (discussed infra note 127), but he also has used the term with reference to specifically legal principles and "meanings" established by the common law, Bowen v. Massachusetts, 487 U.S. 879 (1988) (Scalia, J., dissenting), or the general practices of "our criminal law tradition," Jones v. Thomas, $109 \mathrm{~S}$. Ct. 2522, 2531 (1989) (Scalia, J., dissenting) (discussed infra text accompanying notes 182-210). Outside a specifically legal context, he has defined "tradition" with great particularity and specificity, so as to limit sharply its utility for expansive constitutional rulings. See Michael H. v. Gerald D., 109 S. Ct. 2333, 2341-46 (1989) (holding that societal "tradition" should be defined as specifically as possible).

28. Whether there really is such a thing as a "standard conservative historiographical claim" is another matter. Sec Farber, The Originalism Debate: A Guide For The Perplexed, 49 Orio ST. L.J. 1084,1086 (1989) (no clear agreement among "originalists" about what constitutes "intent" or how historical evidence should be used); $c f$. Brest, The Misconceived Quest for the Original Understand$m g, 60$ B.U.L. REv. 204, 229 (1980) (major difference between moderate originalists and nonorginalists is attitude). Moreover, some non-originalists, like Michael Perry, have expressed much the same attitude as Scalia. M. Perry, Morality, Politics, ANd Law 121-79 (1988). The difference of opinion concerns whether originalism or non-originalism is really the lesser evil. See Bork, Neutral Princtples and Some First Amendment Problems, 47 IND. L.J. 1 (1971); Bork, The Impossibility of Finding IVelfare Rights in the Constitution, 1979 WASH. U.L.Q. 695; Meese, Construing the Constitution, 19 U.C. DAvis L. REv. 22 (1985) [hereinafter Meese, Construing the Constitution]; Meese, Touard a Jurisprudence of Original Intention, 2 Benchmark 1 (1986).

29. Scalia, Originalism, supra note 15 , at 856 . Otherwise, he says, the promoters of such theories would have articulated them in music, rather than in words. In characterizing those theories, Scalia appears to be referring to recent scholarly expositions of the meaning of language, and in particular to J. White, When Words Lose Their Meaning (1984). White's theory, however, has to do with how texts create interpretive communities, and does not involve any allegation concerning the incoherence of all language.
}

30. Scalia, Originalism, supra note 15 , at 856 .

31. Id. at $856,860-61$. 
also an "unwritten Constitution" from which one may seek guidance, a "history of meaning in the words contained in the Constitution without which the Constitution itself is meaningless." ${ }^{32}$ The study of language can thus supplement, if not displace, the problematic and time-consuming study of history in constitutional cases, and the study of words' conventional, "ordinary" meanings can provide an alternative to ad hoc "policy" assessments for interpreting the Constitution whenever history fails.

Moreover, for Scalia, basing an entire constitutional philosophy on studying history has other drawbacks, too. Sometimes studying history is simply not productive. Thus, despite the historicist strain in his own opinion upholding juvenile execution, ${ }^{33}$ he nonetheless is "confident that public flogging and hand-branding would not be sustained by our courts,"34 regardless of what the evidence concerning those practices in eighteenthcentury America might show to a professional historian. In part, this is because certain provisions of the Constitution are themselves "evolvable,"35 written with a view toward their "varying application and varying circumstances." ${ }^{\text {38 }}$ But it is also due to the fact that even originalist historiography is prey to the "inevitable tendency of judges to think that the law is what they would like it to be,"37 which will, in the ordinary course of events, just as inevitably "cause most errors in judicial historiography to be made in the direction of projecting upon the age of 1789 current, modern values." ${ }^{38}$ Even under a strict "originalist" philosophy, let alone a "faint-hearted" one, the net result of constitutional interpretation will always be, at worst, an evolutionary legal and social "compromise."39 And these originalist styles are therefore the approaches best designed to fulfill what he sees as the intrinsically conservative role of the Constitution (or of the law) as "a brake"40_but not an absolute roadblock-against change.

Scalia uses the term "original meaning," 41 to describe his approach to constitutional adjudication, and at his Senate confirmation hearings he took pains to distinguish it from popular notions of "original intent."42

32. Scalia, Is There An Unwritten Constitution?, 12 Harv. J.L. \& PuB. Pol'Y 1 (1989).

33. Stanford v. Kentucky, 109 S. Ct. 2969 (1989) (discussed infra note 127).

34. Scalia, Originalism, supra note 15 , at 861 . For some reason, flogging and torture seem to be the examples of preference among conservative theorists when they seek to demonstrate that there are unwritten constitutional standards to which even they would concede legitimacy. See, e.g., R. POSNER, The Federal Courts 194 (1985) (due process would prohibit given state from adopting more brutal elements of traditional Islamic criminal punishment, because there is national consensus against it).

35. 1986 Hearings, supra note 5 , at 108 .

36. Id.

37. Scalia, Originalism, supra note 15 , at 864 .

38. Id.

39. Scalia, supra note 14 , at 4 .

40. Id.

41. 1986 Hearings, supra note 5, at 108.

42. Id. 
While suggesting that there was "not a big difference" 43 between the two in practice, he made clear that "the text of the document and what it meant to the society that adopted it" would always be for him "the starting point and the beginning of wisdom." should discover that the secret intent of the framers was quite different from what the words seem to connote, it would not make a difference,"45 as far as he was concerned. And the reason, once again, is partially a practical one: sticking to the "plain meaning of a text" ${ }^{\text {"46 }}$ makes it easier for judges (and Justices) to frame their decisions in terms of "categorical rules." "17 The framing of decisions in such terms not only helps assure predictability and uniformity, but also serves as a further constraint on judicial discretion. The judicial system as a whole is more constrained because broader decisions mean more new cases fit within the old ones. But, as Scalia sees it, sitting Justices are more constrained by broader rulings, too. "Only by announcing rules do we hedge ourselves in,"48 says Scalia-a goal he plainly finds desirable, and toward which his "word"oriented originalism is a well-adapted means.

What this amounts to, of course, is a profoundly positivist and textualist vision, inclined not only to minimize the role in constitutional interpretation of policy or the general contemplation of contemporary morals, but at times the Framers' actual intent, even when that intent is knowable. The history of language's ordinary social and dictionary meaning assumes for Scalia an enhanced role in constitutional adjudication, partially replacing "statutory" purpose-and completely eliminating any unconstrained examination of evolving social values. In the interest of coherence, it follows for him that the interpretation of precedent must be bound by the same rules as the interpretation of other relevant texts. Unless the text or the precedents say to look to purpose or intent, ${ }^{49}$ both are to be analyzed in a basically philological way.

Thus, Scalia's approach is not only positivist and textualist, but also formalistic, in many respects a throwback to more "mechanical" days. In its fixation on the historically and socially isolated documentary text, it represents a contemporary constitutional analogue to the "practical" New Criticism, pioneered by I.A. Richards and John Crowe Ransom, ${ }^{50}$ which

\footnotetext{
43. IN.

44. Id.

45. Id.

46. Scalia, Rule of Law', supra note 27 , at 1184 .

47. Id.

48. Id. at 1180 .

49. Scalia, Originalism, supra note 15 , at 863 (giving evolutionary content can be required by precedent, as well as by constitutional text).

50. J. Ransom, The New Criticism (1941); I. Richards, Practical Criticism (1929). As Richards saw it, "criticism itself is very largely . . . an exercise in navigation." Id. at 11. Among the vices to be avoided were "sentimentality," "stock responses," and extraneous "doctrinal adhesions," as well as "general critical preconceptions." Id. at 13-17; see also C. BROOKS, THE WeLL-WrovGHT
} 
dominated American literary studies in the 1940's and 1950's-when Antonin Scalia was coming to adulthood in his decidedly literary household in Queens, New York. ${ }^{\text {s1 }}$ The law governs because it is the law, and wherever possible the precise wording of the law is to be taken as determinative. When one looks at precedent, the first thing one looks for is the jurisprudential rule. ${ }^{52}$ Decisions are to be arrived at in new cases by looking at the challenged law or practice, and by measuring it against the text, including, if necessary, the "glosses" on that text rendered in earlier authoritative readings. All this is to be done in as semantically precise a way as possible, so as to minimize one's own interpretive discretion and the influence of social, political, or moral context, except as that context has made its way directly into the "ordinary meaning" of relevant, legally operative words.

The practical implications of this complex combination-a rigorously confined methodology, frequently tending to remove the "text" even from its original historical context, but which is nonetheless selected as one's governing convention for frankly pragmatic reasons-depend upon the setting within which it operates: what the text says, what the precedents say, and the kinds of arguments one is trying to answer. If "you can't beat somebody with nobody," it matters a great deal whether or not the other side has somebody. As we shall see, in Scalia's view it is the Court's conservatives, and not just its liberals, who frequently have "nobody" in constitutional criminal procedure cases.

But the process by which these constitutional beliefs and attitudes likely were formulated deserves a probing word or two before their application can be fully understood. Antonin Scalia is a "somebody" too. ${ }^{53}$

URN (1947). See generally 1 R. WeLlek, A History of MODERN CRitricism (1955) (overview and survey). For a defense of the New Critics from the charge that their ahistorical literary "formalism" was intrinsically politically reactionary, see W. HANDY, KANT AND THE SouTHERN NEW CRITICS 23, 42 (1963). Another scholar, while cautioning in extremely strong terms against the highly distorting consequences which inevitably flow from overzealous and naive attempts to import the methods of other disciplines into legal analysis, has also noted the resemblance between certain trends in legal interpretation and the literary views of the New Critics. R. Posner, LAw and Literature: A Misunderstood ReLation 220-47 (1988).

51. See infra text accompanying notes $99-104$.

52. Indeed, Scalia has indicated that, over time, his commitment to reading cases for broad rules is, if anything, growing, as he is increasingly impressed by the practical utility of doing so for achieving uniformity, predictability-and now control of the Supreme Court's docket. Scalia, Rule of Law, supra note 27 , at $1178-80$.

53. Some basic biographical information is called for at this point. As an undergraduate, Scalia attended Jesuit-run Georgetown University, receiving his B.A. in history in 1957. Graduating from Harvard Law School in 1960, Scalia attended the "citadel" of conventional legal education in its Legal Process heyday, after which he practiced law in Cleveland for eight years before becoming a legal academic, first at the University of Virginia and then the University of Chicago. He also served in a number of White House and Justice Department posts, including Assistant Attorney General at the Office of Legal Counsel during the Ford Administration.

Scalia's father emigrated to this country from Sicily as a teenager, and subsequently became a professor of Romance languages at Brooklyn College. His mother, also a first-generation Italian immigrant, became an elementary school teacher. Their only child, Antonin, was born into the ItalianAmerican community in Trenton, New Jersey, in 1936 and moved to Queens, New York, as a small 


\section{B. From Original Sin to Original Intent}

Discovering the sources of Scalia's commitment to his special version of text-oriented "originalism" presents an interesting and slightly tricky problem. Other originalists display a markedly greater consistency between what they find in the constitutional document and their own political views. The motivation of some of originalism's exponents is hardly obscure: It is not unkind to attribute former Attorney General Meese's espousal of it, for example, to a result-oriented interest in eliminating affirmative action and overruling Roe $v$. Wade. ${ }^{54}$ Yet, given Scalia's off-theCourt reputation for being gregarious and charming, and the many preconfirmation predictions that he would be a powerful conservative consensus-builder, ${ }^{\mathrm{sB}}$ his frequent use of particularly strong language in his opinions, even against his fellow "conservatives," ment to his methodology and his faith in the correctness of his views arises from sources in his character running deeper than his specifically political convictions. While Scalia plainly does reach conventionally "conservative" positions on abortion and affirmative action-and on construing the civil rights acts as well-both his tone and his not infrequent outcome "contradictions" suggest strongly that a facile focus on any supposed "resultorientation" in explaining his approach to constitutional adjudication does not do justice to the Justice.

In exploring the possible deeper sources of Scalia's positivist, formalist, and practical originalism, a good place to start is by considering the broader popular appeal of present-day "originalism." The revival of "originalism" as a popular constitutional rhetoric and as a persistent

child. He obtained his secondary education at Xavier High School, a Catholic military academy in Manhattan, where he was known to his classmates as both brilliant (graduating first in his class, as he later did at Georgetown) and extremely conservative. Antonin Scalia, Current Biography Yearbook 502 (1986).

Scalia's scattered autobiographical comments also display a marked ethnic and (perhaps slightly vicarious) class consciousness (if his father was a college professor, he also was a first-generation immigrant). He has also displayed a distinct resentment of (and exceptionally personal negative animus toward) "the Wisdoms and the Powells and the Whites," Scalia, The Disease as Cure: "In Order To Get Beyond Racism, We Must First Take Account of Race," 1979 Wash. U.L.Q. 147, 152, whose ancestors participated in the oppression of African-Americans and who, in his view, now seek to rectify the effects of that oppression at the expense of newer immigrants through affirmative action. See also Johnson v. Transportation Agency, 480 U.S. 616, 677 (1986) (Scalia, J.) (defending "unknown, unaffluent and unorganized" workers whose interests he feels are ignored by proponents of affirmative action). Such unusually strongly phrased remarks add much credence to the idea that Scalia's personal and family history is of exceptional importance to understanding his approach to constitutional issues. His family's recent immigrant status, and his father's subsequent professional career in languages, see infra text accompanying notes 99-104, further suggest that "linguistic" issues were central to his intellectual development, as was, of course, the fact that the daily experience of Catholics of his generation involved a considerable exposure to Latin.

54. See Meese, Construing the Constitution, supra note 28, at 25.

55. Sep Jost, Scalia: A Charning Hard-liner, L.A. Daily J., Aug. 11, 1986, at 2, col. 5; Adler, Lite Wire on the D.C. Circuit, Legal Times, June 23, 1986, at 9.

56. Sep, e.g., Webster v. Reproductive Health Servs., 109 S. Ct. 3040, 3064-65 (1989) (Scalia, J., concurring) (severely criticizing Justice O'Connor's concurring opinion). 
theme in contemporary politics-its undeniable resonance with strong currents in contemporary culture-is probably most accurately attributable not merely to political hostility toward certain of the Court's recent outcomes, but to a deeper revivalism among the broader public. ${ }^{57}$ That is the revival of religious fundamentalism, particularly Christian fundamentalism, as a popular political, spiritual and social ideology. The analogy between a literal interpretation of the religious Bible and an "originalist" interpretation of the civil one is not hard to make or understand. The attitude of self-assurance toward discerning God's intent displayed by fundamentalist interpreters of the Bible bears striking similarities to the assurance displayed by many constitutional "originalists" concerning the ability of contemporary judges to ascertain and apply the intent of the Founding generation.

For the most part, previous evaluations of new Supreme Court Justices have either sought to explain their subject's judicial behavior in secular, political terms or reasoned backward from their judicial output to their presumed political starting-point. But in uncovering the likely sources of Justice Scalia's deeply held views a less secular approach may be more productive. The seeming contradiction between his assumed "conservative" political sympathies and his emerging constitutional philosophy in criminal procedure cases may well be best resolved through consideration of his own religious roots. Although attributing his views to libertarianism, as some have done, ${ }^{58}$ is not entirely inaccurate, libertarianism crosscuts, and frequently conflicts with, Scalia's basic positivism. A strictly political approach to his conception of the judicial role therefore emphasizes the results over the deeper structure of his constitutional perspective. ${ }^{88}$

Since the appointment of Louis D. Brandeis to the Court in 1916, it has become common to speak of the Supreme Court's "Jewish seat." But since the time of Roger Taney, Roman Catholics have been considerably more conspicuous in their presence on the Court. ${ }^{60}$ Currently, three of the

57. See Horwitz, The Meaning of the Bork Nomination in American Constitutional Histor, 50

U. PITT. L. REv. 655, 663 (1989) ("originalists and constitutional literalists are fundamentalists").

58. See, e.g., Postrel, Explaining the Supreme Court's Seeming Mood Sxing of Late: It Appears that Some Justices Haz'e Gone "Libertarian" on Us, Wash. Post Nat'l Weekly Ed., July 10-16, 1989 , at 23 (Court observers may have misunderstood or underestimated importance of libertarian strand of American conservatism).

59. At the same time, however, it would also be wrong to underemphasize his libertarian-type commitments. As he has eloquently said,

Judges are sometimes called upon to be courageous, because they must sometimes stand up to what is generally supreme in a democracy: The popular will. Their most significant roles, in our system, are to protect the individual criminal defendant against the occasional excesses of that popular will, and to preserve the checks and balances within our constitutional system that are precisely designed to inhibit the swift accomplishment of that popular will.

Scalia, Rule of Law, supra note 27, at 1180 . Interestingly, Scalia singles out in this passage as his two special concerns those elements of constitutional law which, it is suggested here and in Carter, supra note 2 , are the two most generally neglected by the leading theorists.

60. According to one recent scholar, Catholics have often been chosen precisely because they u'ere Catholics. See Perry, The Life and Death of the "Catholic Seat" on the United States Supreme Court, 
nine Justices-Brennan, Scalia, and Kennedy-come from that tradition. It would be surprising in the extreme if their religious backgrounds were to be without significance for their behavior on the Court. This is especially true of Justice Scalia, upon whom the influence of his religious education is particularly well-attested. ${ }^{61}$

Ordinarily, to the extent that they consider the impact of Catholicism on the derivation of constitutional beliefs at all, jurisprudential theorists have tended to focus on the "higher" elements of the Catholic legal tradition. ${ }^{62}$ Most frequently considered has been Thomas Aquinas' conception of a higher "natural law," an external theory of behavior and of justice whose principles are discernible through the application of practical reason. ${ }^{63}$ According to Aquinas, any attempted act by a secular sovereign must be evaluated in light of such external principles to determine its legitimacy, for

[h]uman law has the nature of law in so far as it partakes of right reason. . . . But in so far as it deviates from reason, it is called an unjust law and has the nature, not of law, but of violence. ${ }^{64}$

... [Consequently], man is bound to obey secular princes in so far as this is required by the order of justice. Where-fore if the prince's authority is not just but usurped, or if he commands what is unjust, his subjects are not bound to obey him. ${ }^{65}$

The practical implications of this Thomist duty to resist the "violence" of "unjust laws" can obviously be substantial. It is plain, for example, that

6 J.L. \& Pol. 55 (1989) (tracing history of appointments of Catholics to Court).

61. Stengel \& Beckwith, Warm Spirits, Cold Logic, Time, June 30, 1986, at 30 (Scalia remembered as having been "heavily influenced" by his Catholic education; Scalia had "close, religious, and intellectually challenging" homelife). According to those who knew him at the time, Scalia was "an archconservative Catholic during high school," Molotsky, Men in the News: Judge With Tennaty and Charm, Antonin Scalia, N.Y. Times, June 17, 1986, at 31, col. 2, who was "perturbed by the liberalizations in the Catholic Church" in the early 1960's, Adler, supra note 55, at 9. According to a high school classmate, at the age of seventeen Scalia "could have been a member of the Curia," Current Biography Yearbook, supra note 53, at 502.

62. See L. WeinReb, Natural Law and Justice 54-63 (1987).

63. According to Aquinas,

[I]n order that the volition of what is commanded may have the nature of law, it needs to be in accord with some rule of reason. And in this sense is to be understood the saying that the will of the sovereign has the force of law; otherwise the sovereign's will would savor of lawlessness rather than law.

T. Aquinas, Summa Theologica I-II, Q. 90, art. I, quoted in Mensch \& Freeman, A Republican Agenda for Hobbesian America?, 41 U. FLA. L. Rev. 581, 584 n.7 (1989). On the other hand, Aquinas also had a theory of language which would seem to parallel Scalia's rather closely. According to Aquinas, "That first signification whereby words signify things belongs to the first sense, the historical and literal. That signification whereby things signified by words have themselves also a signification is called the spiritual sense, which is based on the literal and presupposes it." T. AQuinas, supra, at $\mathbf{I}, \mathbf{x}$, quoted in Hirsch, Counterfactuals in Interpretation in INTERPRETING LAw AND Literature: A Hermeneutic ReAder 62 (1988) (S. Levinson \& S. Mailloux eds. 1988).

64. T. Aquinas, Summa Theologica I-II, at Q. 93, Art. 3 (Fathers of the Dominican Province trans. 1942).

65. Id. II-II, at Q. 104, Art. 6. 
many Catholics relied upon this obligation as a basis for their radical and active opposition to the war in Vietnam. ${ }^{66}$ It might not be surprising, therefore, to see a Catholic Supreme Court Justice, especially a conservative one, assume a similar view: for example, to set aside a past decision upholding a right to choose abortion on the ground that "killing babies" violates natural law. Still, Justice Scalia has made no such gesture, ${ }^{87}$ and in fact has gone directly against his own bishops' teachings with respect to capital punishment. ${ }^{68}$ Indeed, if any of the Catholic Justices has adhered to a Thomist analytic construct in approaching moral issues, it is easier to make the case that his name is Brennan, not Scalia. ${ }^{69}$

Sanford Levinson, together with Thomas Grey, ${ }^{70}$ has recently added another dimension to the analysis of the relationship between Catholicism and constitutional interpretation. ${ }^{71}$ In discussing different traditions in constitutional interpretation, Levinson analogizes to what he calls (with appropriate anti-reductionist disclaimers) the "catholic" and "protestant" approaches to the derivation of religious doctrine. His taxonomy focuses on two issues: the relationship of written text (the Scripture) and unwritten "tradition" to the derivation of doctrine, and the question of who may determine authoritatively what the doctrine is. For Levinson, constitutional "protestants" are those who emphasize "the exclusivity of written Scripture or text as the basis of doctrine;"72 constitutional "catholics" are those who recognize "the legitimacy of unwritten tradition in addition to Scripture" as a sound basis for interpretation. ${ }^{73}$ Institutionally, "protestants" believe in non-hierarchical, communitarian interpretation; "catholics" recognize a legal "papacy" and look only to the Supreme Gourt as the source of ultimate interpretation. ${ }^{74}$

According to Levinson, all Supreme Court Justices are invariably "catholic" on the second question, if for no other reason than that it concerns their own institutional prerogatives as members of the sole legiti-

66. See D. Berrigan, The Trial of the Catonsville Nine (1970); D. Berrigan \& R. Coles, The Geography of Faith (1971). See generally F. du Plessix Gray, Divine DisobedienCE: Profiles in Catholic Radicalism (1970) (summarizing and explaining Catholics' history of civil disobedience).

67. Scalia's Webster opinion, see supra note 56, concerns the distinction between law and politics-between textually specified and other rights-rather than "killing babies." Predictions that he might take a more overtly "Catholic" approach were made at the time of his nomination. See Comment, Judicial Restraint, supra note 5 , at 228 (collecting media citations).

68. See U.S. Catholic Bishops' Statement on Capital Punishment (1980).

69. See S. Levinson, Constitutional Farth 211 n.9 (1988).

70. Grey, The Constitution as Scripture, 37 Stan. L. REv. 7 (1984).

71. S. LEvinson, supra note 69 , at 27-53.

72. Id. at 27. Of course, Levinson's description of "protestantism" glosses over distinctions between fundamentalists and Lutherans in their attitudes toward the scripture. Thomas Grey has pointed out that there is a somewhat dated quality to Levinson's taxonomy as well; post-Vatican II ecumenism has reduced the sharpness of distinctions between traditional Catholic and Protestant approaches to the Scripture. Grey, supra note 70, at 9-13.

73. S. Levinson, supra note 69 , at 27.

74. Id. 
mate interpretive body. ${ }^{75}$ On the first, methodological question, he sees no necessary correlation between the holding of "protestant" or "catholic" views and the positions one takes in particular cases, or even the more general politics of any particular individual. ${ }^{76}$ Each "rhetoric of justification" supports conflicting outcomes in any particular case. ${ }^{77}$ Thus, "Justices Black and Harlan easily fit, respectively, into the designations of 'protestant-catholic' and 'catholic-catholic.' "78

But if Justice Scalia's educational and family background is so emphatically Roman Catholic, ${ }^{79}$ why does his textualist constitutional analysis sound so resolutely "protestant"? Perhaps the high Thomist natural law tradition and the Levinsonian taxonomy both miss the central point. The life of the ethnic American Catholic coming of age in the mid-twentieth century has not been logic, but experience; and in understanding that experience a page of the Baltimore Catechism may be worth a volume of Aquinas. ${ }^{80}$ As William James pointed out almost a century ago, the religious experience comes in many forms; it both reflects and shapes more general intellectual and emotional processes. ${ }^{81}$ Learning Catholic doctrine concerning moral matters-which Justice Scalia surely did during the 1950 's at the Catholic military high school he attended and as an undergraduate at Georgetown ${ }^{82}$ - may not be what counts. What counts may be the habit of mind he acquired in the course of learning it.

Consequently, a more fruitful route toward understanding Justice Scalia's jurisprudential world-view may lie not in "High Church" theological discussions, but in the testimony of fellow pre-Vatican II American Catholics such as Garry Wills, who began his own career as a conservative analyst with William F. Buckley's National Review ${ }^{83}$ (of which the

75. Id at 39. Scalia's Australian Bar speech specifically confirms his view that a written constitution requires a single authoritative interpreter. Scalia, supra note 14, at 17-18.

76. S. LEvinson, supra note 69.

77. Id. at 33 .

78. Id. at 51 .

79. Sfe supra notes $53,55 \& 61$.

80. It is well-known that until the 1960's, "[t]he Baltimore Catechism remained the staple of the Catholic Sunday school and of children's religious instruction in general. . . . [Despite some 1940 revisions,] the question-and-answer format remained central and the memorization of scholastic terminology was still necessary." J. Dolan, The American Catholic Experience 391 (1985). After further revisions in the 1960's, "The clarity and precision of the Baltimore Catechism era has given way to less precise, popular expressions of theological truths." Id. at 441.

81. W. James, The VARIETIES OF Religious EXPERIENCE (1902).

82. Sip supra note 53.

83. J. Judis, William F. Buckley, Patron Saint of the Conservatives 157-58 (1988). Buckley himself is also notoriously fond of words, particularly multisyllabic Latinate ones.

It should of course be made clear-and in the most forceful terms possible-that the analysis suggested here with respect to Justice Scalia is not intended to account for the views of all Catholics, or of non-Catholics who also adopt a textualist approach to constitutional interpretation. It is not a question of religious dictation. See Perry, supra note 60, at 92 (Kennedy, Scalia, and Brennan-like their Catholic Supreme Court predecessors-have never followed a simple "party line"). Justice Brennan, another Catholic, does not share Scalia's vision, for example; Chief Justice Rehnquist, a non-Catholic, shares quite a lot of it. One of the better-known textualists in fact disliked Catholicism intensely. See H. Black, JR., MY Father: A Remembrance 104 (1975) ("The Ku Klux Klan and Daddy, so far 
young Antonin Scalia is said to have been an early devotee) ${ }^{84}$ What Wills says of the ordinary Catholic's experience of the Latin Mass might apply just as easily to Scalia's literalistic approach to the constitutional text: The proper thing for the priest and his parishioners to do at Mass, as for the Justice looking at the Constitution, was to "[m]ove through it with intent fidelity, with legalistic care." pre-Vatican II America was that of inhabiting "a world of quaint legalisms," portantly, for purposes of analogizing to Scalia's special, ahistorical version of originalist interpretation, these "quaint legalisms" assumed greater importance in the Catholic's daily experience precisely because the Church of the Forties and Fifties did not engage in any real historicism-that is, "intent"-oriented "originalism"- with respect to its own doctrine, or its interpretation of the world: "The church judged things not out of a deeper antiquity, but from outside time altogether." ${ }^{87}$ The approved historiographic methodology was not, therefore, an easy harkening to general or unwritten tradition, as Levinson would describe the "catholic" constitutional vision. It was the constant consultation of a written, though extra-Scriptural tradition, serving much like precedent, which appropriate institutions had specifically and authoritatively handed down. As many critics of the Supreme Court's use of history have suggested is true of the Court, for Catholics of Scalia's vintage, "The church's past, so far as it could be said to have one, was glimpsed in quick raids made on history, meant to capture proof-texts showing that . . our doctrines, were all there in the Fathers. . . ."88 This attitude reflects a clericallyrun version of what is sometimes disparagingly called "law office history." ${ }^{88}$

According to Wills, the purpose of this carefully-induced world-view was to reduce thought to "formulae" reflection on ultimate historical or moral values, or on any abstract higher law: "The mode of theology was constant-a simultaneous linking and

as I could tell, only had one thing in common. He suspected the Catholic Church.").

Still, in determining the constitutional methodology any person happens to find congenial, individual life experience matters a great deal. To be sure, even Justice Scalia's own development has probably not been quite as linear as this section generally argues. Different people "process" the same experience in different ways, and differences in their other life experiences of course then change them further. The received interpretation of the life of Robert F. Kennedy provides a good example of the latter point. Always privately devout, his early public career was self-righteously harsh and overzealous, and yet (at least according to his friendly biographer) following his well-known traumas, he ended not as a true-believing son of Baltimore, but as the acolyte of Greek tragedians and Albert Camus. See A. Schlesinger, Jr., Robert F. Kennedy and His Times (1978).

84. Adler, supra note 55 , at 10 .

85. G. Wills, Bare Ruined Choirs: Doubt, Prophecy, and Radical. Religion 74 (1972).

86. Id. at 35 .

87. Id. at 17

88. Id. at 20 .

89. L. Levy, Original Intent and the Framers' Constitution 312 (1988).

90. G. WILLS, supra note 85 , at 16 . 
severing in the Scholastic distinguo. To know the terms was to know the thing, to solve the problem. So we learned, and used, a vast terminology," reality and capture it in rules." ${ }^{\prime 22}$ If a young person was by the second grade studiously parsing out the answer to questions like, "What three things does it take to make a $\sin$ mortal?,"93 it was but a small leap, fifteen years later, for the first-year law student to parse out criminal law concepts like "the elements of the offense." In Scalia's generation, traditional Catholic education and traditional legal education thus conspired to promote an exceptionally strong respect for "the rules laid down"94 even if, indeed especially if, the rules laid down seemed "quaint."

There is also more direct evidence than Wills' general childhood recollections to confirm that the urban Italian-American's religious experience in Scalia's home borough of Queens, New York, during the time of the Justice's childhood, "was a Catholicism closer to the peasant roots of its practitioners than to the high intellectual traditions of Catholic theology and philosophy."'9s As another Queens-raised Italian-American Roman Catholic lawyer prominent in American public life has pointed out, for one coming from such a milieu:

[T] he patterns of conduct and concern that are formed early in life don't really change a great deal, at least not fundamentally . . . the instincts born in the incense and the Baltimore catechism . . . operate through .... every legislative session, even every decision on what words to write down for other people to read. . . . ${ }^{98}$

And, it follows, decisions concerning how to read the words that others-whether Framers, legislators, or prior Courts-have written down for you.

As Mary McCarthy wrote, growing up Catholic in pre-Vatican II America was "like learning a language early; the effect is indelible." Moreover, McCarthy, like Wills and Cuomo, also identified the learning of her special "language" with what she saw as a specifically Catholic tendency to attach a special importance to words. For her, the reason lay

91. Id.

92. Id. at 32 .

93. According to the 1960's version of the Catechism, the answer is: "[F]IRST, the thought, desire, word, action or omission must be seriously wrong or considered seriously wrong; SECOND, the sinner must know it is seriously wrong; THIRD, the sinner must fully consent to it." ST. JOSEPH BALTIMORE CATrChIsm 32 (rev. ed. 1964). It also bears noting, in this catechetical connection, that Scalia's approach to constitutional adjudication bears a resemblance as well to the European civil lawyer's treatise-oriented question-and-answer approach.

94. This phrase is borrowed from Mark Tushnet. See Tushnet, Following The Rules Laid Down:

A Critique of Interpretirism and Neutral Principles, 96 HARv. L. REv. 781 (1983).

95. M. Cuomo, The Diaries of Mario Cuomo 463 (1984).

96. Id. at 13 .

97. M. McCarthy, Memories of a Catholic Girlhood 24 (1957). 
not just in patterns of early religious training, but in the Catholic tradition of giving children their names based upon the personal qualities and life histories of the different saints; as a result, she said, "names have more significance for Catholics than they do for other people." ${ }^{\text {98 }}$ As Wills suggests, "terms" may simply matter more, and be more deeply felt to hold explanatory keys. If "to know the terms was to know the thing," a virtually obsessional textualism in constitutional interpretation may be habitual, if not indeed automatic. Linguistic essentialism seems second-nature. To reject "policy" as a starting point is thus a rather easy thing to do.

Moreover, for Antonin Scalia in particular, the special importance his culture attached to "words" was almost certainly even more deeply inbred than it was for the average pre-Vatican II American Roman Catholic. For him, the importance of literalism was-literally-brought home. Scalia's "deeply religious" immigrant father, Brooklyn College Professor of Romance Literature, S. Eugene Scalia, was a specialist in and strenuous critic of the art of literary translation. Like son, like father: Throughout his career Eugene Scalia believed strongly that, to avoid destroying "what is unique" in reading any text, "literalness is . . essential." 100 In fact, the elder Scalia was so skeptical of the value of translation that he doubted the worth of the entire enterprise to which he had devoted his professional life: "[T] he most that a translation can hope to do," he said, "is to stimulate an interest." 101 It was only by direct "communion" with the original "page"102 itself that a work could ever really be appreciated-only by being able to interact directly with the text's original, and not translated, words. There is little mystery, therefore, why his only child, Antonin, studied Latin for six years and classical Greek for five. ${ }^{103}$ Believing, like the New Critics, that "[a] poem is a poem, not this plus that,"104 the first Professor Scalia almost surely brought home the message

98. Id. at 112 .

99. Marcus \& Schmidt, Scalia Tenacious After Staking Out a Position: Supreme Court Nominee's Vieu's Attuned to Reagan Era Conseriative Philosophy, Wash. Post, June 22, 1986, at A1, col. 2, A16, col. 1.

100. S. Scalia, Carducci: His Critics and His Translators in England and america, 1881-1932, at 90 (1937) [hereinafter S. Scalia, CarduccI]. Somewhat in the manner of J.B. White, whom his son disparaged, see supra note 29 , Justice Scalia's father (reflecting central theme of modern Italian history) also was a man who believed strongly in a language's ability to create, or at least reaffirm, a sense of national identity. See S. Scalia, Luigi Capuana and His Times 37, 39 (1952). Toward the end of his life, Professor Scalia worked on an additional project, overlapping in some respects with the career of his son. His final work was an English translation of the memoirs of Philip Mazzei, an itinerant Enlightenment surgeon, adventurer, and entrepreneur, involved in the American and French Revolutions who also was an associate-and sometimes business partner-of Washington, Jefferson, Madison, Marshall, and Franklin. See Philip Mazzei: My Life and Wanderings (M. Marchione ed. S. Scalia trans. 1980). One of the few translators whose literalism the elder Scalia seemed to like was someone named "Tribe." S. SCALIA, Carducci, supra, at 88-90.

101. S. Scalia, Carducci, supra note 100 , at 95.

102. Id.

103. Marcus \& Schmidt, supra note 99, at A16, col. 2.

104. S. Scalia, Carducci, supra note 100 , at 45 , of. J. Ferete, The Critical. Twilight 86 
he so vigorously asserted in his own "texts." At the dinner table forum, as in the period's Catholic education generally, the distinction between vague notions of authorial "intent" and the poet's-or the Church's-precise "words" must have been drawn especially sharply for Antonin Scalia; and the fundamental importance of preferring strict textual fidelity over loose interpretive "translation" must have been strongly emphasized.

Equally importantly, Justice Scalia's proclivity for a positivist textualism in constitutional interpretation is most likely further reinforced by the pre-Vatican II American Catholic's social experience outside the Church itself, an experience that helps account for the pragmatic tone in which Scalia expresses his views on constitutional interpretation, as well as for their specific content. Going back at least as far as Al Smith, Roman Gatholics in American public life have repeatedly been confronted by a general perception that, if not Thomists, they are something worse: direct subordinates of the Bishop of Rome. It is a cliche, of course, that the successful 1960 Presidential campaign of Massachusetts Senator John F. Kennedy, Harvard's Catholic "favorite son," liberated them from any absolute preclusion, even on the electoral side. But that same campaign also raised the public profile of this sometimes dormant issue at a particularly interesting-and potentially significant-time. The price of having the bar lifted was a most explicit declaration, before a Baptist ministers' convention in Houston, just as the devout young Catholic Antonin Scalia was himself graduating from the Harvard Law School, that in public life American Roman Catholics will "believe in an America ... where no religious body seeks to impose its will directly or indirectly upon the general populace or the public acts of its officials." ${ }^{105}$ Although the requirement of a promise to subordinate "personal morality" to the "public com-

(1977) (essence of New Critics' position was "a general insistence . . . that priority belongs to the poetic object, not to its effect; that the poem is autonomous, closed, self-contained, complete, and to be contemplated as a pattern of knowledge").

105. Remarks of Senator John F. Kennedy on Church and State, Greater Houston Ministerial Association (Sept. 12, 1960), reprinted in T. WhIte, The Making of the President 1960, at 391 app. C (1961). See generally J. Higham, Strangers in the Land: Patterns of American NaTIVISM, 1860-1925 (1988) (history of anti-immigrant movements); R. HofSTADTER, The PARANOID Strle in American Politics and Other Essays (1965) (conspiracy theories in American histary). Nor has anti-Catholicism entirely disappeared in certain quarters friendly toward the President who appointed Scalia to the Court. See, e.g., J. SwagGart, Catholicism and Christianity (1986), ciled in K. Keating, Catholicism and Fundamentalism: The Attack on "RomanISM" BY "Bible Christians" 87 \& n.4 (1988) (famous 1980's televangelist demonstrates hostility toward Catholicism). The rise, and eventual decline, of the same social phenomenon also can be traced through the decisions of the Court. See Mueller v. Allen, 463 U.S. 388 (1983) (Court upholds state's tuition tax credit plan designed and adopted for obvious benefit of parents who send their children to Catholic and other parochial schools); Cantwell v. Connecticut, 310 U.S. 296 (1940) (overturning cunviction of man distributing anti-Catholic "fighting words"); Pierce v. Society of Sisters, 268 U.S. 510 (1925) (Court strikes down state law designed to prevent Catholic parents from sending their children to Catholic schools).

Establishment Catholic scholars have themselves noted that this strong prejudice has tended to lead to intellectual isolation on the part of many American Catholics, see J. Ellus, AmErican CatholicIsm 114-16, 150-51 (1956), an isolation that reinforces the separateness of their intellectual culture. The Keating and Ellis books both carry the Church's imprimatur. 
mands of the Constitution"106 has become a widespread social ritual, Levinson points out the continuing high visibility of "the enactment of this most subtle degradation ceremony in the confirmation process of nominees to the United States Supreme Court, especially where the potential judges are Catholic, as with Antonin Scalia and Anthony Kennedy."10z

In 1960 from the Baptist "right" and in 1986 and 1987 from the prochoice "left"-a strong suspicion of closet papism still pervades the secular political culture's evaluation of potential Catholic appointees to high office. This same ritual of abjuration remains a widespread phenomenon in contemporary electoral politics as well: It is perhaps a reverse compliment, arising from respect for Gatholicism as a particularly potent faith, that when they speak out on public issues Catholic public officials must still take special pains to distance themselves from their Church, to distinguish their public from their private selves. ${ }^{108}$ Hence, it is not surprising that even other Catholics argue that the true test of Scalia's judicial qualities will be whether his opinions appear to be "precast" on grounds of ideology. ${ }^{108}$

The constant repetition of such a ritual of self-division does not mean, of course, that the ritual therefore necessarily becomes hollow; just the opposite may well be the case. The more the ritual is repeated, the more sincere it may become. The New Testament itself, in a passage repeated annually as part of the standard Catholic liturgy, admonishes Christians "[t]o render unto Caesar the things that are Caesar's." Court, what is true of Caesar's coin, in the context of the parable, may be equally true of Caesar's Constitution, and even Thomas Aquinas recognized the responsibility of Catholic judges to give the fullest possible sway to secular law where their social role demands it. ${ }^{111}$ As Justice Scalia himself has stated, in praise of Catholics' "differentness," for the contemporary American Catholic "the ways of the world and the ways of

106. S. Levinson, supra note 69 , at 56 .

107. Id. Levinson notes that Justice Brennan has also made essentially the same declaration. Id.

108. M. Cuomo, supra note 95, at 466; see also Cuomo, Religious Belief and Public Morality, N.Y. Rev. Books, Oct. 25, 1984, at 32. Of course, the efforts of Catholic public officials to keep the religious hierarchy away from their public lives also require the cooperation of that hierarchy. Father Robert Drinan's decision to leave Congress, ordered by the Pope, suggests that the issue of church involvement is not an imaginary one, even if the fact that Drinan was a Jesuit priest makes his a somewhat special case. President Kennedy suggested that he would have resigned the presidency if a direct and unavoidable conflict between his religion and his secular responsibilities had arisen. For the particularly unpleasant difficulties that yet another Italian-American Roman Catholic lawyer from Queens recently experienced in obtaining the Church's cooperation in maintaining this public/private distinction, see G. Ferraro, Ferraro: My Story 211-40 (1985). Needless to say, in the postWebster era, in which the abortion issue will become more prominent in political campaigns, the salience of this church-state/public-private issue is likely to be very much on the rise.

109. Cuomo, Keynote Address by Govemor Mario Cuomo on August 11, 1986 Before the American Bar Association, 1986 DET. C.L. REv. 1169, 1176.

110. Matthew 22:15-21.

111. T. AQuinas, supra note 64 , at II-II, 63:4; 64, 6, obj. 3 \& ad. 3. See generally J. Noonan, Persons and Masks of THE LAW 17 (1976) (outlining Aquinas' views). 
Christ's law are not always the same. Things that are perfectly lawful, perfectly permissible for everyone else . . . [are] . . . not necessarily lawful and permissible for us."112 The key to being a good Catholic, and by extension a good Catholic Justice, is "being strong enough to obey"113 the law that actually applies. As trite (and ecumenical) as citations to A Man for All Seasons are fast becoming, it still cannot be an accident that, in defending the concept of a written Bill of Rights before the Australian Legal Convention in 1987, Scalia approvingly referred his audience to Robert Bolt's "Sir" (not "Saint") Thomas More for the proposition that such human documents necessarily-and properly-embody "Man's laws, not God's." "114 And the central tension in the play itself revolves precisely around More's effort to use "legalisms," words, and technicalities to avoid a direct conflict between his personal religious values and the demands of his public role.

Given his background, and the conceded fact that legal views are "inevitably affected by moral and theological perceptions,"115 it is neither biographically surprising, nor entirely unwelcome, to hear Scalia say, in the vein of a positivist credo, "I have never been able to isolate obligations of justice, except by defining them as those obligations that the law imposes."116 Given his perception that God also creates "laws," failing to honor strictly the human ones within their appointed realm would leave Scalia with little but the Church's laws to fall back upon as a way of providing moral content to the Constitution if he did not will himself to see that document as largely self-explanatory. Yet it is precisely this alternative, of referring directly to his Church, that he and other public officials of a Catholic background have been required to foreswear. In order to participate at high levels of the American government, the American Roman Catholic, as a matter of political reality, is under heavy pressure to embrace one form or another of a radical positivism, eradicating "personal preferences," eschewing any version of non-interpretivism, adhering as strictly as possible to the broader society's "terms."

112. Kramer, Justice Scalia Praises the "Differentness" of Catholics, L.A. Daily J., June 1, 1987, at 4, col. 4; $c f$. G. WIL.s, supra note 85, at 1 ("We grew up different.").

113. Kramer, supra note 112, at 4, col. 4. Similarly, as a judge, "You must apply laws you don't like and you don't interject personal biases." Dixon, BC Press Grills Scalia, The Kingsman (BrookIyn College student newspaper), Oct. 23, 1989, at 5 (quoting Justice Scalia). "I adhere to the text where the text is clear. Where the text leaves room for interpretation, I am guided in what it means by our societal traditions, not by a show of hands. . . 'Hey, maybe I don't like the result either." " Scalia al BC, supra note 12, at 5 (quoting Justice Scalia). But see supra note 27 for a more complete discussion of how Scalia actually invokes "tradition."

114. Scalia, supra note 14 , at 21 .

115. Scalia, Morality, Pragmatism, and the Legal Order, 9 Harv. J.L. \& Pub. Pol'y 123 (1986).

116. Id. at 125. Typically, however, he pairs this observation with the observation that many fewer issues really are "moral" ones than political rhetoricians would have us believe. Much more frequently, they are really issues of "prudence or utility"-which, for his purposes, is to say legislative or administrative issues. Id. at 124-25. 
Still, this is not an entirely uncomfortable outcome for someone in Scalia's position. If the experience of growing up Gatholic was that "to know the terms was to solve the problem," a radical literalism resolves the practical political problem posed for the would-be Catholic Justice by a means toward which he or she may already be psychologically pre-disposed: a rigid interpretive methodology, to be justified in pragmatic terms. Moreover, such a profound self-division both reinforces, and is reinforced by, a devotion on the "public" side to a whole series of categorical distinctions-executive versus legislative, ${ }^{117}$ interstate versus intrastate, ${ }^{118}$ legal versus "political"118 — which helps explain other dimensions of Scalia's judicial persona. The Constitution becomes a constricting and absolutely binding text that one is proud to follow closely because of-not in spite of-the fact that doing so sometimes frustrates one's personal desires. Judging with an eye toward framing "categorical rules" both advances and arises from the same need: as Scalia himself points out, rules are so plainly useful for "hedging ourselves in." Following the "original" Constitution and all its corollary precedential "rules" provides a further way of proving that one is "strong enough to obey."

The result, of course, is a thoroughly dualistic constitutional methodology: the "Scholastic distinguo" in legal rather than clerical garb, a methodology arising directly from a deeply rooted desire to "codify reality and embody it in rules." 120 It also is a theory that demands personal, as well as institutional, "judicial self-restraint"- -and a theory so socially and psychologically essential that all deviations from it must be denounced in the sharpest terms. Thus, as the gospel says, "In the Beginning was the Word"121 — and the "Word" was God: the short and simple recipe for a catechetical Constitution.

\section{Catechetical Constitutionalism in Griminal Procedure: Theme and VARIATIONS}

Before ascending to the D.C. Circuit in 1982, Scalia devoted the major portion of his intellectual energies to administrative law. As the co-editor of Regulation and chair of the Administrative Conference of the United States, in the course of an impressively prolific academic career, he estab-

117. Morrison v. Olson, 487 U.S. 654 (1988) (Scalia, J., dissenting) (dissenting-alone-to independent counsel provision of Ethics in Government Act).

118. CTS Corp. v. Dynamics Corp. of America, 481 U.S. 69, 94 (1987) (Scalia, J., concurring in part and concurring in judgment); Tyler Pipe Indus. v. Washington Dept. of Revenue, 483 U.S. 232, 254 (1987) (Scalia, J., concurring in part and dissenting in part).

119. See Stanford v. Kentucky, 109 S. Ct. 2969 (1989) (discussed infra note 127; suggesting capital punishment opponents address arguments to legislature); Webster v. Reproductive Servs., $109 \mathrm{~S}$. Ct. 3040, 3065-66 (1989) (Scalia, J., dissenting) (attacks on people who would "lobby" the Supreme Court by sending it mail).

120. G. WiLıs, supra note 85 , at 16 .

121. John 1:1. 
lished himself both as a superb administrative law technician and as an advocate of Chicago-style regulatory reform. ${ }^{122}$ Prior to his appointment to the D.C. Circuit, Antonin Scalia had given no written indication of his views on criminal procedure. ${ }^{123}$

Once appointed to the Circuit Court, however, Scalia quickly impressed observers as a strong "law and order" man. Though his printed opinions as a circuit judge dealing with criminal procedure issues are few, and the measure is a crude one, it is notable that every one of his D.C. Circuit opinions dealing with criminal procedure-four majority opinions and one dissent-supported the prosecution side. ${ }^{124}$ Upon his nomination to be an associate justice, he was consequently attacked by liberal groups, such as the Nation Institute and the ACLU, for what they saw as his unsavory support for prosecutors over defendants. ${ }^{128}$ Although criminal procedure issues formed only a subsidiary part of his opponents' overall critique, ${ }^{126}$ neither those who opposed him nor those who supported him seemed to doubt, despite his scant record, that he would continue the Burger Court's gradual erosion of procedural protections for criminal defendants in the interest of a tougher "law and order" policy.

What he has done since his Supreme Court confirmation, and his subsequent, more extensive involvement in criminal procedure issues, must therefore strike such observers as surprising. Solid in his conviction that the text or texts can answer almost every question, he has not been hesitant to apply his view of their meaning on behalf of criminal defendants whenever the constitutional language or the language of authoritative precedent seems to dictate that he do so. ${ }^{127}$ As his general theoretical pro-

122. The latter advacacy implicated much larger issues than mere tinkering with the various enactments of which he had established himself as a master. By the early 1980's, in fact, the journal he edited might well have been re-named De-Regulation, a process to which Scalia saw no obstacles. His analysis was grounded in a larger theory of democracy, statutory interpretation, and separation of powers: To the extent that Congress delegated broad discretion to administrative agencies, it was precisely the function (or, anyway, a part of the function) of presidential elections to determine the direction in which that discretion was to be exercised. For similar separation of powers reasons, he also distinguished himself as a leading academic opponent of the legislative veto.

123. See King, supra note 5 , at 6 .

124. See American Civil Liberties Union, Report on the Civil Liberties Record of Judge Antonin Scalia 6-7 (Sept. 8, 1986).

125. Most ominous in the view of Audrey Feinberg, who testified on behalf of the Nation Institute, was Scalia's dissenting opinion in United States v. Richardson, 702 F.2d 1079, 1086 (D.C. Cir. 1983), in which Scalia went out of his way to comment adversely on the "public disrepute" which the exclusionary rule brings upon the judiciary, even though Richardson itself presented double jeopardy, rather than exclusionary rule, issues. 1986 Hearings, supra note 5 , at 263.

126. S't 1986 Hearings, supra note 5 , at 168-223, 248-310.

127. It is obvious that this literalistic positivism also has a dark side. In Scalia's vision, a judge's beliefs have no off-setting weight whatever in constitutional adjudication if a dictionary reading of the Constitution's words points some other way. This is of course the old "dog bites man" version of the positivism story, and it consequently is not emphasized in the text. Although a number of the cases discussed in this Section suggest that positivism Scalia-style may confer dividends on criminal defendants in certain situations, his opinion in the juvenile execution cases, Stanford v. Kentucky, $109 \mathrm{~S}$. Ct. 2969 (1989) (plurality), to cite the most stark example, makes clear that it is also capable of producing extremely harsh results. Moreover, in the context of capital punishment, the impersonal and rigid 
nouncements suggest, this dictation takes two forms: definitional and ruleoriented. Sometimes the text's individual "terms" solve the problem by themselves; their very definition establishes the relevant categories, and the analysis consists in deciding whether the practice or activity at issue is of the sort the term describes. At times when individual textual terms cannot answer the entire question, the text-and, more often, precedent-can nonetheless be read as a source of rules.

Discussion of two types of cases follows: (1) "definitional" cases where Scalia perceives the challenged practice or activity to collide directly with the Constitution's text or prior precedent, and (2) "rule-oriented" cases where making some form of balancing or policy choice seems inescapable, either because the relevant constitutional provision is open-ended, or because the implications of past precedent do not seem clear. ${ }^{128}$ As we shall

approach displayed in Scalia's opinions takes on a chilling tone. Applying his literalistic positivism with a vengeance, he not only disposed of the juvenile execution cases in short order, but converted the moral question they presented into a mathematical one.

He began, as usual, linguistically. Because the Constitution prohibited only punishments that were both "cruel and unusual," he said, it would not be enough for the petitioners merely to show that the execution of juveniles was "cruel." Id. at 2975 . To satisfy Scalia, they would have had to show that executing juveniles also was "unusual."

In determining whether juvenile execution was constitutionally "unusual," he said, the Court's "judgment should be informed by objective factors to the maximum possible extent," $i d$. at 2975 (citation omitted), and he thereby promptly reduced the entire enterprise to a simple head-count. Finding that, "of the 37 States whose laws permit capital punishment, [only] 15 decline to impose it on 16-year-old offenders, and 12 decline to impose it on seventeen-year-old offenders," $i d$. at 2975 , he concluded that the fact that so many states permitted the execution of juveniles by itself demonstrated that the petitioners had not established "the degree of national consensus this Court has previously thought sufficient to label a particular punishment cruel and unusual," id. at 2975-76. His mechanical jurisprudence thus reduced the function of the Court under the Eighth Amendment to administering a judicial coup de grace to rarely-authorized penalties that "evolving standards" of social reality had already demonstrably made vestigial.

Instead of finding evidence of capriciousness or unusualness in the infrequency with which capital punishment has actually been carried out against juveniles in recent American history, Scalia's positivist assumptions led him to exactly the opposite conclusion: "[I]t is not only possible but overwhelmingly probable that the very considerations which induce petitioners and their supporters to believe that death should neter be imposed on offenders under 18 cause prosecutors and juries to believe that it should rarely be imposed." Id. at 2977. His assumption was that the system intended what it was doing. Similarly, therefore, the fact that the states routinely restricted the driving, drinking, and voting behavior of people in the defendants' age group gave the petitioners' position no support either. To him, the coexistence in state laws of these restrictions, based on teenagers' lack of mature judgment, with the imposition of death sentences on sixteen-year-olds was not evidence of inconsistency or "cruelty." Again, it was just further evidence of how carefully the states had thought through their laws. Id. at 2977-79. At a deeper level, there was a perfectly consistent rule: the states meant to keep these teenagers under paternalistic control, and if the teenagers disobeyed the states' commands, the states very much meant to kill them. Even when prior precedent (concerning "evolving standards of decency") authorized more expansive interpretation, Scalia made clear that it took very strong evidence-in fact, "the operative acts (laws and the application of laws) that the people have approved," id. at 2979 , for even a "faint-hearted originalist" actually to do anything if: (a) the Constitution said "unusual" and (b) a number of duly enacted statutes indicated that juvenile executions were not. Since his entire opinion is based upon a distinction between "or" and "and" (that is, that petitioners had to show both cruelty "and" unusualness in order to prevail), it is notable that Scalia has also argued elsewhere that "or" is the same as "and." See Honig v. Doe, 484 U.S. 305, 334 (1988) (Scalia, J., dissenting) ("or" can be used as conjunction, not just as disjunctive); see also Thompson v. Oklahoma, 487 U.S. 815, 820 (Scalia, J., dissenting) (setting forth same pro-capital punishment argument in earlier juvenile execution case).

128. Any number of other Scalia opinions in criminal cases would illustrate the formalist- 
see, in the first situation text or precedent-in fact virtually anything-wins over ad hoc policy. In the second, more ambiguous situation, a scrupulous lawyerly logic almost always supplants, or at least sharply limits, the scope of the inescapable policy question. Even when policy becomes part of his analysis, Scalia insists that the policy interests to be weighed actually exist in the context of the case before him, rather than merely being argued or asserted hypothetically. Pressing the facts of a case hard for the true implications of asserted policy interests in the immediate situation helps him to curtail broad contemplation of policy issues by the Court. If facts can be made determinative in the absence of clear substantive text or rules, then procedural rules-in particular, the burden of persuasion-can be made to deliver a "mechanical" answer even when the substantive rules do not.

This review of Scalia's opinions shows one thing more. Regardless of their outcome, his opinions consistently evidence a profoundly dichotomous world view, implicit in his social and political position, but not entirely reflected in his more easy-going and "commonsensical" general statements. Often using severe and forceful language, his opinions consistently display a strong, pretheoretical sense that life is hard, and that legal and other choices are harsh as often as they are clear. They also demonstrate an unflinching belief that inequity, or at least "policy" irrationalities, have to be accepted as the price-or at least the result-of being "strong enough to obey" such strict textual self-discipline.

textualist theme, as do the opinions discussed in the text. Among these are: Schmuck v. United States, 109 S. Ct. 1443, 1453 (1989) (Scalia, J., dissenting); United States v. Taylor, 108 S. Ct. 2413, 2423 (1988) (Scalia, J., concurring); Houston v. Lack, 108 S. Ct. 2379, 2385 (1988) (Scalia, J., dissenting); United States v. Owens, 484 U.S. 554 (1988); United States v. Mendoza-Lopez, 481 U.S. 828, 846 (1987) (Scalia, J., dissenting); Hitchcock v. Dugger, 481 U.S. 393 (1987); United States v. Dunn, 480 U.S. 294, 305 (1987) (Scalia, J., concurring). Several of these are omitted because Scalia's position turns upon the application of his method to factual issues, of. Dunn, 480 U.S. at 302 ("a barn is a barn"), or the interpretation of statutes or court rules, rather than the Constitution's text. See, e.g., Lack, 108 S. Ct. at 2387 (meaning of "delivered to the clerk"); Owens, 484 U.S. at 560 (Federal Rule of Evidence); Schmuck, 109 S. Ct. at 1454 ("mail fraud not fraud and mail"). The recurrence of this same essentialist locution also raises other interesting and, for present purposes, thesis-reinforcing issues. His father liked to make similar kinds of statements, too. Cf. S. Scalia, Carducci, supra note 100, at 45 ("la] poem is a poem"); S. SCAlia, Luigi Capuana and His Times, supra note 100, at 107 ("muck is muck"). Interestingly, only one of Scalia's 22 criminal procedure opinions in his first three Terms really seems to contradict the thesis set forth in the text. See Mathews v. United States, 485 U.S. 58, 67-68 (1988) (Scalia, J., concurring) (rejecting semantics and formalism).

A review of Scalia's votes in criminal cases shows that he supports the government approximately eighty percent of the time, a figure that seriously undermines any argument that he is primarily a "libertarian." Moreover, Scalia also seems to receive a disproportionate number of opportunities to write pro-defendant majority opinions-he writes approximately $50 \%$ of the time-when Justice Brennan has the power of assignment. Possibly Justice Brennan sees certain types of potential in his junior colleague, and seeks to "lock him in" to certain positions for future years. Of course, more mundane considerations - the simple process of constructing majority coalitions by giving the assignment to the coalition's most tenuous member-may also be a factor. 


\section{A. "Terms" and Rules}

Two of the following opinions are strictly word-bound; the third, which involves reliance more on precedent than on text, shows Scalia's tendency to read cases for their rules. Each ultimately supports the criminal defendant's position. And they all illustrate the depth and rigidity of his textual and formalistic positivism: they all are cases where his catechetical adjudicative formula yields a definitive result.

\section{1. "A Search is a Search"}

Shortly after his appointment, Scalia gave both his supporters and opponents pause regarding their earlier assumptions. In his opinion for the Court in Arizona v. Hicks, ${ }^{129}$ he showed himself to be anything but the ideological "law and order" conservative others had taken him to be.

The issues Hicks presented may be stated in a variety of ways: the meaning of a "search" for purposes of the Fourth Amendment, the scope of the "plain view" exception to the warrant clause, and the possible need for a policy-based relaxation of the Fourth Amendment's "probable cause" requirement for truly minimal intrusions. Scalia answered the last question with a surprisingly firm "no," and used a formalistic approach to answer the first two with a privacy-protecting, police-constraining version of textual strict constructionism.

Hicks arose on April 18,1984, when a bullet was fired through the floor of one apartment and into the apartment below, injuring its occupant. In response to this emergency, police officers forced their way into the apartment from which the shot appeared to have been fired. They found it vacant, but seized three weapons and a stocking-cap mask, which were scattered around the premises. While one officer was calling in the serial numbers of the recovered weapons to the stationhouse, the others waited, generally observing the apartment's contents. One of the idle officers, Officer Nelson, noticed an unusual amount of high-quality audio equipment in what was a "squalid and otherwise ill-appointed" apartment in a poor section of town. Suspecting that the goods were stolen, Nelson decided to secure their serial numbers too, in order to have headquarters check whether they had been reported as stolen goods. Because the serial number on one of the components could not be seen from where he stood, Nelson moved it very slightly in order to determine what the

129. 480 U.S. 321 (1987). Wasserstrom \& Seidman, supra note 9, at 28-31, have also focussed, disapprovingly, on Hicks as a "formalistic" opinion. Judge Moylan, of the Maryland Court of Appeals, has noted its cool "Aristotelian logic" and devotion to precedent a good deal more approvingly. See Moylan, Judge Moylan Analyzes 1986-87 High Court Tern, Criminal Practice Manual, Trial. Practice Series 368 (1987), quoted in King, supra note 5, at 21 (also discussing Hicks at some length). King adopts the same approach used here in discussing Hicks-that is, starting the discussion by examining the dissents. See infra text accompanying note 132. 
number was. After copying the serial number, he then replaced it undamaged in its original position.

As it turned out, Officer Nelson's suspicions were correct. At his subsequent trial for armed robbery, the defendant in Hicks did not dispute that the police officers were justified in entering the apartment without a warrant due to the exigent circumstances presented by the mysterious gunshot that seemed to emanate from the apartment. He sought to have the evidence suppressed anyway, however, on the ground that the police officer's minimal additional action-the temporary lifting of a turntable-extended beyond the legitimate justification for the officers' presence. Therefore, he asserted, it could not have been justified in the absence of probable cause or the invocation of an additional Fourth Amendment exception, such as "plain view." The state conceded that the officer had lacked probable cause to lift the turntable, but argued that his actions were nonetheless within the scope of the "plain view" exception. Both the trial court and the Arizona Court of Appeals rejected these arguments and suppressed the evidence. According to the Supreme Court, "[b]oth courts-the trial court explicitly and the Court of Appeals by necessary implication-rejected the State's contention that [the officer's] actions were justified under the 'plain view' doctrine"130 of Coolidge v. New Hampshire. ${ }^{131}$ Surprisingly, in view of previous assumptions, Antonin Scalia, a member of the Court for only a few months, wrote the majority opinion affirming the courts below.

As it happens, the significance of the Court's ruling in Hicks is more easily discerned by examining the dissents. Doctrinally speaking, Hicks involved clarification of some ambiguous language in Coolidge. The Coolidge plurality, in recognizing a "plain view" exception (originally developed in the context of warrantless seizures, rather than searches), said that an investigating officer legitimately on the premises should not be prevented from seizing evidence when it is "immediately apparent to the police that they have evidence before them"; at the same time, it said, what it called "the 'plain view' doctrine may not be used to extend a general exploratory search from one object to another until something incriminating at last emerges."132

Justice O'Connor, writing in dissent for Justice Powell and Chief Justice Rehnquist, approached the matter in a policy-oriented manner, starting as though these passages from Coolidge were the only words that counted. The dissenters took for granted that the "plain view" exception had always been considered to be a broad one, and that the major-if not only-evil to be avoided was the one the Coolidge plurality had specifically mentioned: Use of the "plain view" doctrine as an excuse for a "full

132. Id. at 466 . 
blown search." Characterizing Officer Nelson's actions as a "cursory inspection of a suspicious item in plain view," which involved none of the "exploratory rummaging" prohibited by Coolidge, Justice O'Connor argued that such a "cursory examination" ought to be constitutionally permissible based upon the lesser evidentiary standard, recognized elsewhere in Fourth Amendment law, of "reasonable suspicion."133 Noting that Justice Stewart, the author of the plurality opinion in Coolidge, had in another case seemed to distinguish between "mere inspection" of potential evidence and more substantial police intrusions, ${ }^{134}$ she argued that Hicks was an appropriate occasion for the Court to establish a sliding-scale "distinction between searches based on their relative intrusiveness,"138 even for searches conducted inside a private residence. "The test," she said, should be "whether . . . law enforcement interests are sufficiently 'substantial" "136 to outweigh the action taken: "Weighed against this minimal additional invasion of privacy are rather major gains in law enforcement."137 Justice Powell, writing separately, gave further support for the law enforcement argument, questioning what exactly Officer Nelson should have done once he noticed the suspicious stereo equipment, and chastised the majority for "trivializing the Fourth Amendment" by distinguishing between slightly moving and merely looking at objects in "plain view." 138

O'Connor's characterization of the majority opinion in her dissent as establishing a " 'bright-line' test" resting heavily upon "the theoretical advantages of the 'search is a search' approach"139 is, in fact, exactly right-although the policy-oriented theory she apparently had in mind is not the one from which Scalia operated. For Scalia, the issue was quite clear: When the police officer moved the stereo, he went beyond "viewing"; he performed a search, and thereby triggered all Fourth Amendment standards ordinarily relevant to searches. And the matter did not turn on the degree of the intrusion: To perform a "search" a warrant was gener-

133. Hicks, 480 U.S. at 333 (O'Connor, J., dissenting).

134. Id. at 334-35 (referring to Stanley v. Georgia, 394 U.S. 557, 571 (1969)) (Stewart, J., concurring).

135. Id. at 337.

136. Id. at 338 .

137. Id.

138. Id. at 333 (Powell, J., dissenting). Powell also chided the state for having conceded that the officer lacked probable cause for his examination of the stereo, which he believed would have provided an alternative basis for upholding the officer's action; Justice O'Connor, joined (somewhat contradictorily) by Justice Powell, suggested that the majority should have overlooked that concession and found probable cause anyway.

139. Id. at 339 (O'Connor, J., dissenting). The majority's use of the phrase occurs $i d$. at 325 . Justice Powell seemed irritated by it as well. See id. at 332 (Powell, J., dissenting). O'Connor's mention of "bright-line theories" probably was intended as a reference to Fourth Amendment arguments suggesting that the Court set exceptionally clear rules in cases where its desire is to control the behavior of front-line law enforcement officers. See Alschuler, Bright Line Feter and the Fourth Amendment, 45 U. PrTr. L. Rev. 227 (1984); Whitebread, supra note 10. This is not, however, what Justice Scalia seems to have been thinking about. 
ally required and, even when there were excuses for not getting a warrant, a "search" was nonetheless prohibited in the absence of probable cause. Noting ambiguity in cases following Coolidge concerning whether full probable cause for searches and/or seizures was necessary in "plain view" situations, ${ }^{140}$ Scalia rejected any "sliding scale" approach and declared that not requiring strict adherence to the traditional probable cause standard "would be to cut the 'plain view' doctrine loose from its theoretical and practical moorings." 141

For Scalia, it did not follow from the fact that circumstances might have allowed the officers to make a warrantless entry that the standard for making a search or seizure, once inside, should be lower than for circumstances in which the opportunity to seek a warrant was available. For the officers to extend their investigative activity in the apartment beyond the particular exigencies justifying their entry, "probable cause to believe the equipment was stolen was required,"142 as was a reason for failing to obtain a warrant. Noting that merely looking at an item already in "plain view" was not for him a "search" at all, ${ }^{143}$ Scalia made clear his view that any affirmative investigative activity designed to uncover evidence was a categorically different thing for constitutional purposes. He therefore sharply rejected Justice O'Connor's dissenting suggestion that the Court recognize a "new thicket of Fourth Amendment law, to seek a creature of uncertain description that is neither a plain-view inspection nor yet a 'full-blown search.' "144

In a striking concluding passage, Scalia confronted what he acknowledged to be Justice Powell's "reasonable"145 question concerning exactly what the officer should have done. He conceded forthrightly that "no effective means short of a search exist"146 for an officer in such situations. However, he nonetheless strongly rejected any appeal to "law and order" ideology as part of Fourth Amendment decision-making: "[T]here is nothing new in the realization that the Constitution sometimes insulates the criminality of a few in order to protect the privacy of us all." ${ }^{147}$ Rather

140. Hick, 480 U.S. at 326.

141. I $l$. at 326 . Scalia also refused to consider the possibility, raised by Justice O'Connor, that the Court make its own evaluation as to whether Officer Nelson possessed probable cause. Scalia held in forceful terms that the state was bound by its concession that probable cause was lacking. Id. at 326 $\mathrm{n}^{*}$. He similarly refused to investigate possible "good faith" theories for upholding the search because review had not been granted on that question. Id. at 329.

142. Id. at 328. Scalia also wrote that the copying of the serial number was not itself a "seizure" requiring probable cause. The transcription did not interfere with anyone's "possessory interest" in tither the numbers or the equipment itself, and thus raised no Fourth Amendment issues. Thus, there would in his view have been no Fourth Amendment problem in the case if the turntable's serial number had been exposed to "plain view."

143. Id. at 325 .

144. Id, at 328 .

145. IH at 329.

146. II

147. Id. 
than create new Burger-style policy analyses, he said, "we choose to adhere to the textual and traditional standard of probable cause."148

The break with the Burger-era reasoning was stark. While O'Connor and Rehnquist in dissent engaged in a frank balancing of law enforcement interests against privacy intrusions (with the usual strong tilt toward the former), Scalia rigorously analyzed the original sources of the Coolidge "plain view" rule. He refused to exploit the Coolidge phrasing's ambiguities to accomplish policy goals, perceiving that Coolidge's distinction between seizure of items in "plain view" and those produced as the result of "a general exploratory search" was not made for the purpose of creating ambiguity for subsequent courts to expand further. Rather, he concluded, Coolidge's ambiguities arose at worst from an effort by its author to illustrate the fundamental polar opposition between "plain view" inspections and completely unconstrained police behavior. For Scalia, the Coolidge Court's use of that common rhetorical device was not to be taken as an invitation to create a mushy middle ground; it was simply a particularly emphatic way of stating a general rule. While expressing sympathy with the position of the police officer-and with Justice Powell's concern for what a conscientious officer in Nelson's position should have done-he nonetheless adopted a profoundly rule-bound position, defending the exclusionary "rule" with steadfastness and even eloquence. Rejecting appeals to instrumentalism, he interpreted both Coolidge and the Constitution with a meticulous and detached rationality to give ordinary-not manipulative-meaning to ordinary language. "Plain view" meant plain view. A "search" meant a search. The basic "terms" counted more than the surrounding rhetoric.

Though the result in Hicks, as O'Connor noted, is indeed consistent with theories of Fourth Amendment jurisprudence which focus on the utility of exceptionally clear Supreme Court rules for purposes of training-and thereby effectively constraining-the police, ${ }^{149}$ Scalia gave no appearance of basing his opinion in Hicks on any such "policy" concern. The predominant theme of his opinion was a resistance to policy interests of all flavors, with the exception of a few nods toward the privacy interests conceded by everyone to be embodied in the Fourth Amendment. $\mathrm{He}$ reached his result through simple, formal reasoning from constitutional language, assuming that those who composed the major relevant precedent(s) would not have abandoned pre-existing analytical categories without explicitly saying so. He made no apologies for the law enforcement consequences of having followed his own methods.

149. See supra note 139 and accompanying text. 


\section{2. "Simply as a Matter of Latin"}

The omens surrounding another of Scalia's formalistic majority opinions for the Court were even less auspicious than they were for Hicks. Coy v. Iowa ${ }^{\mathbf{1 5 0}}$ involved a crime of particular'emotional and political volatility: an adult man charged with forcible child sex abuse, amounting to the "stranger rape" of children. It arose, moreover, against a background of recent precedents suggesting that a defendant in such cases could expect little sympathy from the Court. Once again, however, for reasons based on his own categorical brand of logic, Scalia wrote an opinion for the Court upholding the defendant's right to confront his child accusers directly.

In 1985, two girls, camping in a tent in one of their backyards, were assaulted in the middle of the night by a man wearing a stocking mask, who shined a flashlight in their eyes to diminish their opportunity to observe him. Coy, the next door neighbor, eventually was charged.

The issue presented to the Court in Coy concerned the trial judge's creation of a special "child courtroom," a device of increasing popularity in child sex abuse cases, for the purpose of shielding the girls from possible emotional disturbance arising from their in-court testimony against Coy. ${ }^{151}$ In response to a prosecution request-and without requiring a specific showing that these two girls in particular would be at risk of any emotional harm from physically confronting the defendant-the trial court ordered that a one-way mirror/screen be brought into the courtroom and placed in front of the defense table during the girls' testimony. Thus, the defendant would be able to see the girls during their testimony, while they would be relieved of the obligation of seeing him. Defense counsel protested vigorously, arguing that the screen violated Coy's confrontation clause rights and marked the defendant as dangerous-and therefore guilty-in the eyes of the jury. The trial judge instructed the jury not to draw any conclusions concerning the defendant's guilt from the presence of the screen. ${ }^{162}$ Coy ultimately was convicted, and the Iowa Supreme Court upheld the judgment.

It was not merely the nature of the offense with which Coy was charged that made his Supreme Court challenge to his conviction so doubtful, however. Two terms earlier, in Holbrook v. Flynn, ${ }^{163}$ a unanimous Court, led by Justice Marshall, had rejected another challenge to suggestive courtroom procedures. There, the Gourt held that the presence

150. 108 S. Ct. 2798 (1988). Coy' seems to be an opinion which Justice Scalia himself thinks illustrates his constitutional methodology particularly well. See Scalia, Originalism, supra note 15, at 855.

151. See Berliner, The Child Witness: The Proposed and Emerging Limitations, 40 U. Mrami L. REv. 167 (1985); Bulkley, Introduction: Background and Overview of Child Sexual Abuse Law Reforms of the Mid-1980's, 40 U. MIAMI L. REv. 5 (1985).

152. $108 \mathrm{~S}$. Ct. at $2799-2800$.

153. 475 U.S. 560 (1986). The author served as counsel for Flynn. 
of four armed and uniformed state troopers sitting conspicuously behind the defendant during trial did not inherently prejudice his fair trial rights. Even worse from Coy's point of view was that the Court upheld the conviction in Flynn despite the absence of a cautionary instruction explaining the troopers' presence, or any serious effort to minimize the potential prejudice their presence created by having them change to lessintimidating civilian clothes.

In addition, only one term earlier, the Court had evidenced an exceptionally strong concern for the sensibilities of minor witnesses in child sex abuse cases. In Kentucky $v$. Stincer, ${ }^{154}$ the Court upheld a trial court order denying a defendant the right to personal presence at a pre-trial hearing to test the competency of the very young victim-witnesses to testify against him. Ruling that the presence of the defendant's lawyer was sufficient to protect his rights, it refused to require even the exploration of possible "less restrictive alternatives" such as one-way screens or speaker phones. Moreover, the Court specifically rejected the argument set forth in an amicus brief by the American Psychological Association that per se presumptions that child witnesses in abuse proceedings were invariably traumatized by confronting those whom they had accused were scientifically unfounded. ${ }^{155}$ It thus did not require even a case-by-case showing that harm might actually be caused by the defendant's being present. ${ }^{188}$ While reserving the question Coy presented-the scope of confrontation clause rights of a defendant charged with a child abuse offense at the trial itself-the Stincer Court, in an opinion by Justice Blackmun, noted the numerous other exceptions to direct face-to-face confrontation contained in the Court's hearsay cases. ${ }^{157}$ It thereby gave every indication that it took a broad view of the "special circumstances" that might justify a departure from ordinary courtroom procedures in child sex abuse cases. ${ }^{158}$

Despite this seemingly contrary precedent, however, in Coy itself such tender considerations did not move the Court. In his majority opinion, Justice Scalia articulated a surprisingly strong and absolute defense of what he saw as basic confrontation clause principles. His technique was,

154. 482 U.S. 730 (1987). The author served as co-counsel at oral argument in Stincer.

155. Id. at $746 \mathrm{n} .20$ (limiting application of insights of American Psychological Association brief to, at most, situations where "the opportunity to defend" is directly at issue). The result in Stincer was, moreover, particularly harsh because there was a real basis for believing that the defendant was innocent. The defendant, a recent Cuban immigrant, had serious difficulties making himself understood in English. It is clear from the case's record that at times not even his lawyer could understand him, and the jurors repeatedly interrupted his testimony at the trial to ask the judge to secure someone to interpret his heavily-accented English, a request to which the court only partially acceded. During their own testimony, Stincer's accusers contradicted themselves several times concerning whether anything criminal had taken place, became confused, and ultimately were unable to complete crossexamination, as they dissolved into a state of utter incoherence acknowledged even by the prosecutor. After this proceeding, Stincer was sentenced to twenty years.

156. Id.

157. Id. at 737,738 .

158. Id. 
if anything, even more formalistic than it had been in Hicks. His approach was not just literalistic, but etymological, relying on everything from ancient history to Hollywood Westerns to demonstrate that "confrontation" had a settled and irreducible ordinary usage meaning in the context of an American criminal case, ${ }^{169}$ even when many of the Court's own precedents suggested that it had previously read the clause more flexibly.

Apparently out of deference to the "originalist" historicist convention, Scalia began his opinion with what was little more than an historical grace note, subsequently twisted to serve more essentialist, linguistic ends. Tracing the right to face-to-face confrontation back to "the beginnings of Western legal culture," Scalia noted at the outset additional historical "indications that a right of confrontation existed under Roman Law." ${ }^{180} \mathrm{He}$ then almost casually distinguished the Court's previously-recognized confrontation clause exceptions concerning out-of-court hearsay and limitations on in-court cross-examination. ${ }^{\mathbf{1 6 1}}$ Rather, said Scalia, quoting Justice Harlan, whatever else it does, " "[s]imply as a matter of English" "162 the confrontation clause confers "at least 'a right to meet face to face all those who appear and give evidence at trial." "163 This was true, he continued, "[s]imply as a matter of Latin as well, since the word 'confront" ultimately derives from the prefix 'con-' (from 'contra' meaning 'against' or 'opposed') and the noun 'frons' (forehead)."164 He further confirmed his historico-linguistic point with a quotation from William Shakespeare. ${ }^{\mathbf{1 6 5}}$

Arguing that both "appearances and reality"186 supported this literalistic view of Sixth Amendment rights, Scalia said that although his citation to such hoary sources was no accident, neither was it an appeal to "originalist" historicism. He referred to those ancient authorities as linguistic illustrations, he said, not as originalist "proof," because doing so served his essentialist approach to human psychology and to his job: "This opinion is embellished with references to and quotations from antiquity in

159. 108 S. Ct. at $2800-01$.

160. Id. at 2800 .

161. Id. Questions concerning hearsay and the scope of cross-examination were, he said, the hard ones under the confrontation clause. In his view, the fact that such doubtful matters had wound up getting litigated had no implications whatsoever for cases closer to the clause's "core." Id.

162. Id. (quoting California v. Green, 399 U.S. 149, 175 (1970) (Harlan, J., concurring)).

163. Id.

164. Id.

165. Id. The quotation from Richard II referred to the venerable tradition of confronting one's accusers: "face to face, and frowning brow to brow." Not content to leave the matter with the Romans, English and Latin dictionaries, and Shakespeare, Scalia added, for good measure, Zachariah Chafee and President Dwight D. Eisenhower. He relied, in addition, upon the (uncited) statement, apparently from somcone like Gary Cooper or John Wayne, "Look me in the eye and say that," to show that his version of "confrontation" had deep-seated "plain language" meaning in everyday American speech and culture.

166. Id. at 2801 . 
part to convey that there is something deep in human nature that regards face-to-face confrontation between accused and accuser as 'essential to a fair trial in criminal prosecution.' "167 Reiterating his harshly-phrased conclusion from Arizona $v$. Hicks-"[i]t is a truism that constitutional protections have costs"168 -in Coy $v$. Iowa he used even stronger terms to turn the state's own policy argument against it: "face-to-face presence may, unfortunately, upset the truthful rape victim or abused child; but by the same token it may confound and undo the false accuser, or reveal the child coached by the malevolent adult."168 The possibility of "trauma," in short, was an essential and constitutionally-established part of the American adversary plan.

Turning to whether the interest in protecting child witnesses might justify any departure from what he saw as "the irreducible literal meaning of the clause"-namely, "a right to meet face to face all those who appear and give evidence at trial"170 - Scalia then qualified his severe words slightly. Even if a state legislature could somehow create an exception to such a clear and well-established rule, he said, that could not suddenly be done, across the board, by a decidedly novel statute, passed only in 1985. ${ }^{171}$ Even if social changes result in alterations in the long-accepted meaning of textual language, it takes stronger evidence than a brand-new state statute to override the words actually set forth in the Constitution's text. He nonetheless waffled somewhat as to whether it was the statute or the particular practice he was striking down. In the absence of a specific finding that "these particular witnesses needed special protection," he observed, "the judgment here could not be sustained by any conceivable exception"172 to ordinary confrontation clause rules.

The politics of child abuse creates strange alliances, and the dissent from Scalia's opinion was written by Justice Blackmun, for himself and Chief Justice Rehnquist. ${ }^{173}$ Repeating the view expressed in his opinion

167. Id. (citation omitted).

168. Id. at 2802 .

169. Id.

170. Id. at 2803 .

171. Id.

172. Id. Sustaining the use of constitutional harmless error analysis for confrontation clause cases, however, Scalia remanded the case for reconsideration by the Iowa Supreme Court which, because it had found no error in the first place, had never inquired whether the error might be harmless. Justice O'Connor, Scalia's adversary in Hicks, this time concurred in the result but described "face-to-face confrontation" as a constitutional "preference" rather than requirement, and remarked that "nothing in today's decision necessarily dooms . . . efforts by state legislatures to protect child witnesses." Noting that the Court had recognized exceptions in other areas of confrontation clause doctrine, she held that, on different facts, "the strictures of the Confrontation Clause may give way to the compelling state interest of protecting child witnesses." Id. at 2803.

173. Blackmun has a record of being pro-child in abuse, education, and family law cases. Sep De Shaney v. Winnebago County Dep't of Social Serv. 109 S. Ct. 998, 1012 (1989) (Blackmun, J., dissenting); Lassiter v. Department of Social Serv. 452 U.S. 18, 57 (1981) (Blackmun, J., dissenting); Kentucky v. Stincer, 482 U.S. 730 (1987) (Blackmun, J., dissenting). Perhaps more surprisingly, Chief Justice Rehnquist also sometimes seems to share such sympathies. See Burlington School Comm. v. Massachusetts Dep't of Educ., 471 U.S. 359 (1985). 
for the Court in Stincer that the core "confrontation" protected by the Sixth Amendment was not between the accuser and accused, but between the accuser and the jury, Blackmun in Coy denied that face-to-face confrontation was "the irreducible literal meaning of the clause."174 Asserting that the majority's position was not supported by either "logic or precedent," ${ }^{175}$ he argued that past decisions regarding the use of out-of-court declarations at criminal trials had long since established that the supposedly "absolute" rule could be breached. As O'Gonnor had argued in her dissent in Hicks with respect to "crime control," Blackmun's Coy dissent asked the Court to balance the "competing public policies" behind support for what he characterized as Coy's constitutional "preference"176 for faceto-face confrontation, and the state's countervailing interest in protecting the child-accuser's emotional equanimity.

Mocking Scalia's "apparent fascination with the witness's ability to see the defendant," 177 Blackmun said the weakness of the majority's view concerning the "irreducible literal meaning" of the confrontation clause was "reflected in its reliance on literature, anecdote and dicta from opinions that a majority of [the] Court did not join."178 Blackmun himself relied on Wigmore to support a more contemporary and pragmatic view-to describe meaningful cross-examination as what common law "confrontation" was really all about, rather than what he characterized as "the idle purpose of gazing upon the witness or of being gazed upon by him."179 Citing studies demonstrating the prevalence of child abuse and the trauma associated with the trial process for child abuse victims, ${ }^{180}$ Blackmun found no constitutional violation in constructing "child courtrooms" via statute, and even found individual determinations assessing the likelihood of traumatic injury to particular child witnesses to be more than the Constitution required. ${ }^{181}$

Yet Scalia rejected policy arguments that were "soft" on victims just as,

174. Coy v. Iowa, 108 S. Ct. 2798, 2806 (1988) (Blackmun, J., dissenting).

175. Id. at 2806 .

176. Id. at 2808 (citation omitted).

177. Id, at 2806 .

178. Id. (Blackmun also accused Scalia of misusing Richard II); see id. at 2807 n.3. More recently, in a Freedom of Information Act case so sensitive that both parties praceeded under pseudonyms, Justices Blackmun and Scalia engaged in similar semantic combat over the meaning of the world "compiled" in the FOIA phrase "compiled for law enforcement purposes." See John Doe Agency v. John Doe Corp., 110 S. Ct. 471 (1989) (for majority Blackmun cites two different editions of Webster's Dictionary to prove correctness of his definition of "compiled"; Scalia, in dissent, counter-strikes with citation to Roget's Thesaurus).

179. Id, at 2807 (quoting $5 \mathrm{~J}$. WIGMORE, EvidENCE $§ 1397$, at 158 (J. Chadbourne rev. ed. 1974)).

180. Id. at $2808-09$.

181. Id. at 2809 . Although the majority had not reached the issue, Blackmun also considered whether the screen might have been "inherently prejudicial" in due process terms. Claiming that "[a] screen is not the sort of trapping that generally is associated with those who have been convicted," and noting the trial judge's cautionary instruction concerning it, Blackmun concluded that the screen was not inherently prejudicial and certainly no ground for overruling the conviction on the particular facts presented by the case. Id. at 2810 . 
in Hicks, he had rejected policy arguments that were "tough" on crime. Special humane concerns did not justify setting aside a rule, or retranslating a textual "word," any more than the law enforcement benefits of "minimal" privacy intrusions did, when Scalia found the meaning of the Constitution's language to be so culturally and etymologically "clear."

\section{3. "Three Strikes Is Out"}

At the end of the 1988 term, in his dissent in Jones $v$. Thomas, ${ }^{182}$ a relatively minor double jeopardy case, Justice Scalia indicated that his same "ordinary meaning" methodology applies to the sentencing of criminals as well as to their apprehension and trial. Thomas involved a complicated set of facts, and an even more complicated procedural sequence, set against the background of the Court's own convoluted double jeopardy decisions. ${ }^{183}$ Although the constitutional text was less directly available to Scalia as a basis for decision in Thomas than it had been in Hicks and Coy (having developed something of a "policy" life of its own), he had no more trouble deducing, and following, the slightly counterintuitive meaning of the Court's prior rulings than he had previously had in adhering to results derived from a literalistic reading of the text itself.

Thomas had been convicted of, and received separate sentences for, felony murder and the felony during which the death occurred. The felony involved an attempted auto parts store robbery in the course of which a customer was killed. The trial judge imposed the sentences to run consecutively, with a fifteen-year sentence for the attempted robbery to precede a life sentence for felony murder. Thomas promptly filed an application for post-conviction relief in state court, claiming that the trial judge had misinterpreted state law in imposing more than one sentence for the two related crimes. ${ }^{184}$ While Thomas' claim was pending, the state Supreme Court accepted the position for which Thomas was arguing with regard to the interpretation of the relevant sentencing statute in two unrelated cases. $^{185}$ In response, the Governor commuted Thomas' fifteen-year at; tempted robbery sentence to time served, assuming that Thomas would then begin serving his life sentence for felony murder-an understanding later confirmed by the Missouri courts, which formally vacated Thomas' attempted robbery sentence. ${ }^{186}$

Thomas, however, thereupon filed a habeas application seeking his immediate release, arguing that requiring him to serve the life term after the

182. 109 S. Ct. 2522 (1989).

183. See generally Fisher, Double Jeopardy: Six Common Boners Summarized, 15 UCLA L. REV. 81 (1967) (intricate nature of double jeopardy jurisprudence makes it easy for courts to make mistakes); Note, $A$ Closer Look at the Supreme Court and the Double Jeopardy Clause, 49 OHIo ST. L.J. 799, 800 (1989) (Court's opinions create "haphazard results").

184. 109 S. Ct. at 2524-25.

185. Id. at 2524

186. Id. 
(now commuted) fifteen-year term was "completed," violated his rights under the double jeopardy clause, since double sentencing under such circumstances had now been declared improper. ${ }^{187}$ After a number of twists and turns in the lower Federal courts, during which a variety of judges sought different ways to keep Thomas behind bars, ${ }^{188}$ the Eighth Circuit, sitting en banc, decided there was no legal way to do so, and ordered Thomas unconditionally released. The Supreme Court reversed in an opinion by Justice Kennedy, keeping Thomas in jail but crediting the time served on his fifteen-year robbery sentence toward his life sentence for felony murder, a remedy previously imposed by a Missouri court at an earlier stage in this extremely tangled case.

In Justice Kennedy's view, the question presented was a narrow one: Whether the (by now) "admitted violation"189 of Thomas' double jeopardy right not to suffer "multiple punishments for the same offense,"190 created by the trial judge's misinterpretation of the sentencing law and compounded by the Governor's commutation (and the subsequent vacating) of Thomas' first sentence, could constitutionally be cured by a remedy less drastic than unconditional release. To answer it, the Court looked to the "interest that the double jeopardy clause seeks to protect."191 Quoting another recently decided case, Kennedy defined that interest in the "multiple punishments" context as being "limited to ensuring that the total punishment did not exceed that authorized by the legislature."192 In his view, when it came to multiple punishments, the double jeopardy clause was only directed at ensuring "that sentencing courts do not exceed . . . the limits prescribed by the legislative branch."193 However, a problem was created for Kennedy's approach by In re Bradley, ${ }^{104}$ a case in which the Court had held that the defendant's prompt payment of a fine made it impossible for a sentencing court to force him to serve his jail time once it was discovered that it was not entitled to impose both penalties. Conceding that "strict application" of Bradley "would support respon-

187. Id.

188. Id. The Eastern District of Missouri denied Thomas' claim, but was overruled by a divided panel of the Eighth Circuit, which granted Thomas conditional release if the Missouri courts could not find a legal way to re-sentence him. Thomas thereupon requested and received en banc reconsideration of the panel's split decision to pursue his assertion that his release must be unconditional.

189. Id, at 2525 .

190. Id.

191. Id.

192. Id. (citation omitted). Scalia subsequently chastised Kennedy for quoting this case somewhat selectively. Id. at 2532. The case Kennedy cited actually talked about the meaning of double jeopardy in the context of "a single proceeding." When the Halper Court described double jeopardy as being concerned with the courts' fidelity to legislative commands, it was not engaging in a general discussion of double jeopardy principles and values. United States v. Halper, 109 S. Ct. 1892, 1903 (1989). Kennedy acknowledged that the clause also protected against unlawful reprosecutions (following a previous acquittal or valid previous conviction), $109 \mathrm{~S}$. Ct. at 2525 , but in Thomas no such issue was involved.

193. Janes, $109 \mathrm{~S}$. Ct. at $2525-26$.

194. 318 U.S. 50 (1943). 
dent,"195 Kennedy went looking for a loophole through which to escape Bradley's apparent rule. He distinguished Bradley from Thomas based upon the fact that the former case involved two different types of sentences. Noting that the fine and jail time at issue in Bradley were, by definition, not interchangeable - that one could not be "rolled over" into the other-he chose to resolve Thomas simply by crediting the time Thomas had served on the robbery sentence toward the service of the other. ${ }^{196}$ In the majority's view, jail time was jail time.

In frank policy terms, Kennedy justified this outcome by noting that any other decision would "lead to anomalous results." ${ }^{197}$ For one thing, if the Court were to release Thomas, he said, it would establish that such "fortuities" as the sequence in which erroneous sentences had been ordered to be served would assume constitutional dimensions. ${ }^{198}$ Moreover, any other result would actually reward Thomas for being a particularly egregious offender, for it was just such especially evil people for whom consecutive terms were "typically reserved." ${ }^{199}$ The majority summed up its attitude in its concluding paragraph, expressing again the view that the Constitution may best be construed with an eye toward immediate policy objectives:

[D]ouble jeopardy is an area of the law filled with technical rules, and the protections it affords defendants might, at times, be perceived as technicalities. This is irrelevant where the ancient and important principles embodied in the double jeopardy clause are implicated. But neither the double jeopardy clause nor any other constitutional provision exists to provide unjustified windfalls. ${ }^{200}$

In other words, in such special circumstances, "technicalities" be damned. In dissent, Justice Scalia took a radically different approach. To him, the lesson of Bradley and other earlier double jeopardy cases $^{201}$ was

195. Jones, 109 S. Ct. at 2526.

196. Id. at 2527. Kennedy also attempted to distinguish Bradley on the claim that it involved the erroneous imposition of two sentences for a single crime. As Scalia pointed out, however, id. at 2529-30, after the Missouri Supreme Court's ruling Thomas was in exactly the same situation as Bradley. The sentencing court in Bradley was required to choose between two sentences for a single crime; in Thomas, the Court had to choose between two sentences for two crimes which, under State sentencing laws, it had to consider as though they were one.

197. Id. at 2528 (referring to majority's position as desire not to "extend" Bradley, after having just admitted that Bradley directly applies). In Thomas' case, for example, if the original sentencing court had merely ordered Thomas to serve his sentences in the opposite order (or even concurrently), he would still have been in jail with no double jeopardy claim, even after the Missouri Supreme Court ruled that the sentencing court had violated the relevant statute by imposing two sentences. The anomaly that concerned Justice Kennedy was that a ruling releasing Thomas could be perceived as having turned not on the fact that the sentencing court had made a mistake, but on the fact that it made its mistake in one particular fashion.

198. Id.

199. Id.

200. Id.

201. He cited, inter alia, Pennsylvania v. Goldhammer, 474 U.S. 28 (1985) (per curiam); United 
straightforward. Despite the intricate circumstances the Thomas case presented, under Missouri law one thing was clear: "only one of two available punishments could lawfully be imposed for the conduct in question; and . . . the defendant fully satisfied one of the two." ${ }^{202}$ As far as Scalia was concerned, that was the end of the case.

To back up his analysis, Scalia expanded somewhat more upon double jeopardy's purpose, as revealed in precedent, than he had on the purposes of the Fourth Amendment in Hicks or the confrontation clause in Coy. Yet even if double jeopardy analysis involved the consideration of certain general rules and principles, it still most emphatically did not involve a casespecific "policy" component. Disputing at length the majority's contention that double jeopardy raised only separation of powers issues (and this despite his reputation for taking an exceedingly pro-separation view of such issues), Scalia made elaborate use of the Court's past cases to show that double jeopardy also concerned how fair-and final-the criminal justice system was to be. Double jeopardy was directed both toward establishing a principle of systemic finality and (from a defendant's perspective) a principle of "repose," and toward ensuring trial courts' fidelity to relevant legislative commands. ${ }^{203}$ Consequently, though he conceded that an "anomalous result" and "unjustified windfall"204 would result from releasing Thomas, Scalia simply did not believe such unfortunate results were relevant. He ridiculed the majority's notion that the double jeopardy clause was geared merely toward assuring that sentences did not exceed the legislatively-intended maximum, pointing to numerous cases in which double jeopardy had "frustrated" rather than "effectuated" legislative intent. ${ }^{205}$ Even if a legislature created a fifteen-year-to-life sentence for a particular offense, he said, that did not mean that the Constitution would permit suddenly raising a particular prisoner's sentence to a full life term after the prisoner was ten years into serving the lesser term that had originally been imposed. ${ }^{206}$ The rule was not "jail time is jail time", as the majority had suggested. The real rule precedent established, said Scalia, was a simpler one: "Done is done." 207

Much of Scalia's opinion, like the majority's, was given over to fine analyses of other double jeopardy cases to show that his version of the clause's purpose was an accurate reading of prior law, and that the Court had never endorsed "common sense" in the name of policy. Demonstrating that the governing principles and results in double jeopardy cases fre-

States v. Difrancesco, 449 U.S. 117 (1980); Bozza v. United States, 330 U.S. 160 (1947); In re Bradley, 318 U.S. 50 (1943); Ex parte Lange, 85 U.S. (18 Wall.) 163 (1873).

202. $109 \mathrm{~S}$. Ct. at 2529 (Scalia, J., dissenting).

203. Id. at $2532-33$.

204. Id. at 2530 .

205. Id. at $2530-33$.

206. IId. at 2531 .

207. Id. 
quently change depending upon such niceties as whether the allegedly improper sentences were imposed in a single proceeding, ${ }^{208}$ or whether the sentencing statute at issue gave fair indication that "repose" was not to be expected, ${ }^{209}$ he made clear that if there was a potential "anomaly" at issue in Thomas, it was far from the only one around. As he saw it, case-specific outcome vicissitudes were subsumed within a larger and more fundamental vision of the double jeopardy clause's judicially-created "rule."

The attitude expressed in Scalia's closing paragraph could not have contrasted more sharply with that of the majority, for here he states more explicitly than in his opinions in either Hicks or Coy his underlying vision of criminal procedure:

The Double Jeopardy Clause is and has always been, not a provision designed to assure reason and justice in the particular case, but the embodiment of technical, prophylactic rules that require the Government to turn square corners. Whenever it is applied to release a criminal deserving of punishment it frustrates justice in the particular case, but for the greater purpose of assuring repose in the totality of criminal prosecutions and sentences. There are many ways in which these technical rules might be designed. . . . With technical rules, above all others, it is imperative that we adhere strictly to what we have stated the rules to be. A technical rule with equitable exceptions is no rule at all. Three strikes is out. The State broke the rules here, and must abide by the result. ${ }^{210}$

Double jeopardy was not about common sense or law enforcement policy or keeping bad people in places where they could do no harm. As with the Fourth Amendment and the confrontation clause, in the law of double jeopardy, outcome-related "policy" considerations simply had no role. The Court should just learn to live with the unpleasant fact that, every so often, adhering to the "rules" does create windfalls.

\section{B. "Policy" Cadenza: Scalia on Drugs}

Given the realities of the modern Court, it would be unrealistic to expect Scalia, or anyone else, to adhere to any particular methodology with absolute consistency. In criminal procedure, the high caseload alone must exert strong pressure on the Justices to join opinions they might have written differently if they had received the assignment to write. On several occasions, Scalia has joined opinions pursuing a non-positivist course, ${ }^{211}$

208. Id. at $2531-32$.

209. Id. at 2532 .

210. Id. at 2533 .

211. See, e.g., Arizona v. Youngblood, 109 S. Ct. 333 (1988) (relying on officers' good faith to preserve potentially exculpatory evidence); Colorado v. Bertine, 479 U.S. 367 (1987) (supporting "balancing" and discretion by street-level officers). 
and in a certain number of opinions Scalia himself has written he also may seem to have accepted Burger-style "policy interest" balancing. ${ }^{212}$ Yet upon closer analysis, in these cases too he can be observed to display a tendency toward analytic rigidity and a limited tolerance for ad hoc policy-making, even when he acknowledges that "policy" has a place in the decision-making process.

The first of Justice Scalia's criminal procedure opinions to attract general attention for its "liberal" outcome was such a case, although it was not, technically, issued in a criminal case at all. The "liberal" opinion emerged from a pair of civil cases concerning employee drug-testing programs, involving what the Court euphemistically referred to as "an excretory function traditionally shielded by great privacy," chemical analysis of this excretion. In one case concerning railroad workers, Skinner v. Railway Executives' Association, ${ }^{214}$ Scalia voted to uphold such drug tests as reasonable for workers involved in accidents or safetyrule infractions; in the other, involving Customs Service employees, $\mathrm{Na}$ tional Treasury Employees Union v. Von Raab, ${ }^{216}$ he dissented from the "immolation of privacy and human dignity in symbolic opposition to drug use." ${ }^{216}$ Accepting that the cases inevitably involved "reasonableness," the most intrinsically vague standard in the Fourth Amendment's text, he could not evade entirely the need for the Court to make judgments on its own. What he could do was use his positivist formalism to transform the inevitable value judgment these cases required into a more formulaic judgment by strictly applying standard rules concerning the burdens of proof. ${ }^{217}$

The urinalysis cases raised the question of the applicability of the probable cause and warrant requirements to certain special institutional rela-

212. Moreover, being such a pragmatist, he hardly tries to deny it. Despite his distaste for vague and general standards, he says, adopting again his religion-oriented rhetoric, "We will have totality of the circumstances tests and balancing modes of analysis forever-and for my sins, I will probably write some of the opinions that use them." Scalia, Rule of Law, supra note 27, at 1187.

213. Skinner v. Railway Executive Ass'n, 109 S. Ct. 1402, 1418 (1989).

214. Id. at 1402. Skinner also involved some tests based upon reasonable suspicion.

215. 109 S. Ct. 1384 (1989) (Customs Agents Case).

216. Id. at 1398 (Scalia, J., dissenting).

217. To focus on this pro-privacy "balancing" opinion is of course again to emphasize the "man bites dog" side of the story. In Murray v. United States, 487 U.S. 533 (1988), Scalia's formalist impulses took him very much the other way. In that case, he refused to deviate from ordinary rules of proof to guard against possible police manipulation of the "independent source" doctrine in cases involving illegal police action. Murray involved officers who illegally entered a warehouse where they observed marijuana and returned later with what they said was an untainted warrant. The dissenters would have required the police to establish "historical facts capable of ready verification or impeachment," 108 S. Ct. at 2539 (Marshall, J., dissenting) to show that they had (a) already decided to seek a warrant based upon (b) previously-gathered evidence establishing probable cause before the illegal entry occurred. Scalia ruled for the Court, however, that the policy concern for controlling potential manipulation of that doctrine should not be allowed to override ordinary rules concerning how facts are to be proved. Thus, he allowed the government to establish its "independent sources" through the post-hoc testimony of the officers themselves. 
tionships. Four terms earlier, in New Jersey v. T.L.O., ${ }^{218}$ the Court dispensed with both probable cause and the warrant requirement on the grounds of their alleged impracticability in the context of the search of a public high school student locker. One term earlier, in O'Connor $v$. Ortega ${ }^{218}$ also a civil case, a plurality of the Court loosened both requirements for searches of the offices of government employees. In each case, the Court recognized a "special need" relating to the particular institutional context and allowed state actors to make warrantless intrusions based on less than probable cause. T.L.O. was decided before Scalia joined the Court; in Ortega, he concurred in the result. While the plurality in Ortega remanded for a case-specific determination of whether the government employer's search of a government doctor's office, desk, and files was reasonable under "all the circumstances," ${ }^{220}$ Scalia characteristically rejected such a standardless "ad hoc"221 approach. Instead, he voted to remand so that the lower court could determine whether the search at issue would have been reasonable if it had been conducted by a private employer. Stating that private employer searches "to retrieve work-related materials or to investigate violations of workplace rules" were per se "reasonable," ${ }^{222}$ he attempted to convert a relatively concrete private-sector analogy into a public-sector rule. Later, however, Scalia apparently adapted to such precedents, and seemed to soften his resistance to such "balancing" in his opinion for the Court in Griffin v. Wisconsin. ${ }^{223}$ In Griffin, he upheld a warrantless search of a probationer's home based on situation-specific "special need." He did so, however, on the typically narrow ground that the particular search at issue was performed in accordance with a clear and facially constitutional state regulation, specifically addressing this "special need," which diminished the potential for ad hoc "reasonableness" judgments by those responsible for its enforcement.

In the drug-testing cases, he relied on similarly narrow grounds again. Agreeing with the majority in the railroad case, Scalia recognized a "special needs" exception for workers in heavily regulated industries or occupations relating to public safety, where substance abuse related accidents had been a very real problem: As a result, the Fourth Amendment required neither a warrant nor individualized suspicion. In the Customs Agents Case, Scalia switched sides and joined Justice Stevens in a dissent based largely upon the absence of any showing of drug and alcohol use among the agents, as well as the difference between customs agents' and railroad workers' jobs.

218. 469 U.S. 325 (1985).

219. 480 U.S. 709 (1987).

220. Id. at 712 .

221. Id. at 729-30 (Scalia, J., concurring).

222. Id. at 732 .

223. Griffin v. Wisconsin, 483 U.S. 868 (1987). 
In the Customs Agents Case, he focused on what was "dispositively absent" 224 from the government's case: "the recitation of even a single instance in which any of the speculated horribles actually occurred: an instance, that is, in which the cause of bribe-taking, or of poor aim, or of unsympathetic law enforcement, or compromise of classified information, was drug use."225 Oddly, in his view, the government's own brief boasted of the non-existence of the "problem" the drug-testing plan was designed to "correct": only five out of the 3,600 employees who had been tested under the program came up positive for drugs, and the Commissioner conceded that " " $t$ ] he extent of illegal drug use by Customs employees was not the reason for establishing" "226 the program. Scalia distinguished Skinner and other arguably analogous cases ${ }^{227}$ because the "special need" they each recognized related to the specific context in which each challenged practice arose, and concerned needs which had either been proven or were self-evident. With respect to the customs agents, however, he made clear, the government had essentially conceded that its drug-testing program was based on nothing more than "the existence of a 'pervasive social problem." "228 Refusing to make any concessions to the deep national concern over the perils of drug use, he therefore analogized the Customs Agents Case to Delaware v. Prouse, ${ }^{229}$ in which the Court had invalidated random highway license-registration checks designed to address the similarly "pervasive" problem of highway safety. There, the Court concluded that the "marginal at best" contribution of random highway stops to alleviating the "pervasive" safety problem was heavily outweighed by the intrusions they inflicted upon the privacy expectations of the vastly more numerous properly-licensed and registered drivers.

In one of his notable rhetorical flourishes, Scalia sarcastically rejected the government's purely symbolic approach to law enforcement, ${ }^{230}$ and in even harsher terms, the majority's genuflection toward it:

Those who lose because of the lack of understanding that begot the present exercise in symbolism are not just the Customs Service employees, whose dignity is thus offended, but all of us-who suffer a coarsening of our national manners that ultimately give the Fourth Amendment its content, and who become subject to the administration of federal officials whose respect for our privacy can hardly be

224. National Treasury Employees Union v. Von Raab, 109 S. Ct. 1384, 1400 (1989).

225. Id.

226. Id.

227. New Jersey v. T.L.O., 469 U.S. 325 (1985); Bell v. Wolfish, 441 U.S. 520 (1979); United States v. Martinez-Fuerte, 428 U.S. 543 (1976).

228. $109 \mathrm{~S}$. Ct. at 1384,1400 .

229. 440 U.S. 648 (1979).

230. 109 S. Ct. at 1384,1401 ("The impairment of individual liberties cannot be the means of making a point."). 
greater than the small respect they have been taught to have for their own. ${ }^{231}$

If Fourth Amendment principles are ever to be balanced away in "special needs" cases-an approach he had only accepted with reluctance in the first place-Scalia still required that something real must at least be shown to have been gained on the other side. Train workers were one thing, customs agents quite another, and a mere policy "interest" was not the same thing as a demonstrated basis for a policy.

\section{Coda}

Of course not even the Baltimore Catechism, let alone the Philadelphia one, has all the answers all the time. Still, structuring constitutional analysis as though answers can be formalistically derived can frequently have outcome-determinative effects. In Hicks and Coy, the Constitution did "deliver" for Scalia; in Thomas, precedent performed well in its stead. In the drug-testing cases, a more general legalistic logic helped narrow the dispute: The burden of proof rules helped to fill, or at least narrow, constitutional and precedential gaps that might otherwise have required grappling with fundamental questions of policy or value. In each situation, either the textual/philological or precedent-as-rule approach produces almost automatic answers for Scalia and, by extension, relatively reliable Scaliapredictors for observers of the Court. As in the children's game of "rock, paper, scissors," text "takes" precedent, precedent "takes" policy, and ordinary meaning, legalistically construed, takes all. Within limits then, with respect to Justice Scalia himself, "To know the terms is to know the thing."

\section{Other Ghurches, Other Pews: Literalism, Formalism and ACADEMic Culture}

The shortcomings of the textualist methodology applied by Justice Scalia in criminal procedure cases are not hard to see. Inflexibility, pedantry, lack of sensitivity to the needs of law enforcement (or to deterring illegal law enforcement), the absence of a role for decent moral sympathies-these and other similarly obvious limitations only begin the familiar catalogue. Scholars have already criticized such tendencies at length, ${ }^{\mathbf{2 3 2}}$

231. Id. at 1402 .

232. See, e.g., P. Bobbitt, Constitutional Fate (1982) (discussing Justice Black and textualism); Tushnet, A Note on the Revit'al of Textualism in Constitutional Theory, $58 \mathrm{~S}$. CaL. L. Rev. 682 (1985) (all forms of textualism have fatal defects). For his part, Frederick Schauer also has defended them, Schauer, Formalism, 97 YALE L.J. 509 (1988), and has suggested-as is done here-that their past dismissal has been too curt. Schauer then goes on to suggest, somewhat more strongly than is suggested here, that jurisprudence might proceed upon a theory of "presumptive positivism." For Schauer, "formalism merges into ruleness, and both are inextricably intertwined with literalism," id. at 538, a description which would seem to fit Scalia well. 
and they will not be slow hereafter in subjecting Scalia's judicial workproduct to similar critiques.

But in pursuing these familiar themes, scholars may tend to sell such textualist formalism short-in terms of its internal coherence and its consequent persuasive power for Americans outside the academy. Scholars may not like this mode of constitutional adjudication, but there is some evidence that the American people do: it can hardly be a coincidence that Justice Anthony Kennedy, in reversing a conviction for flag-burning, adopted a simple "The Constitution made me do it" line. ${ }^{233}$ Whether such statements make sense in logical or academic terms may sometimes be beside the point. ${ }^{234}$ When confronted with what he knew to be an especially controversial case, Justice Kennedy instinctively reached for the same sort of argument that Justice Scalia routinely deploys, and by doing so he plainly hoped to tap into what he also senses to be the strong appeal of the formalist, deductive model of adjudication within the non-academic culture. To those with the opportunity to dissect theories and cases on a full-time professional basis, the absurdities of such mechanistic thinking may seem overwhelming; however, from the point of view of nonprofessionals, the "method in it" may overwhelm the larger madness. Whatever else may be said about Scalia's literalistic textualism, its claims to internal coherence and rationality are obviously strong. Absurd as it may seem in a generally post-modernist era, the literalist-textualist impulse retains a deep cultural coherence as a mode of legal discourse; it is rational in its own terms-even if, in the view of non-adherents, it is rational to a fault. And in its rationality, however forced, seems to be its power.

If the roots of literalistic formalism are cultural and biographical on Scalia's part, is there any reason to believe that the critique of formalism does not rest on similar foundations? As they have struggled in recent decades to create "grand" new theories concerning constitutional law, progressive scholars may in their own way also have become rational to a fault. However much their politics may have differed from Scalia's, they may nonetheless have accepted far too readily Scalia's basic premise: that it takes a single, internally coherent "somebody" to perform the Supreme

233. According to Justice Kennedy: "The hard fact is that sometimes we must make decisions we do not like. We make them because they are right, right in the sense that the law and the Constitution, as we see them, compel the result." Texas v. Johnson, $109 \mathrm{~S}$. Ct. 2533, 2548 (1989) (Kennedy, $\mathrm{J}$, concurring).

234. Indeed, in an era in which patriotism runs strong and newly proposed constitutional amendments seem to appear almost daily, such arguments may even be somewhat counter-productive. If the flag-burning incident is any example, it suggests that the Justices might better serve the country by taking the blame for such unpopular decisions, instead of blaming the Constitution. Better that opponents of such decisions focus on changing Justices than on changing the Bill of Rights. Thus, to say that Scalia's formalism has a certain socially persuasive power is not to say that it is always the best vocabulary to invoke. 
Court's work in an effective and defensible manner. ${ }^{235}$ As they struggled to construct models of the Court's work whose coherence was abstract or logical, progressive scholars may have underemphasized the social, cultural, and political dimension of constitutional judging-an aspect of their job of which most Justices are no doubt constantly aware. In the process, scholars may also have cut themselves off from vibrant-and perhaps more politically realistic-segments of their own progressive legal culture.

The advent of the Reagan-Rehnquist Court presents an opportunity for some corrective perestroika, as a broader set of constitutional scholars now suddenly experience the same frustrations those concerned with criminal procedure have been facing for almost twenty years-the frustrations of living with a Court pursuing a pre-determined course toward Constitutional retrenchment. Justice Scalia's self-avowed textualism, though vul-

235. Given the variety of theories and analyses that scholars have developed, this may seem like a rather large statement. Still, with very few exceptions, most of these recent schools and theories at their margins do appear to press for some magical unitary source to validate constitutional arguments, or to depart from the concrete realities of constitutional lawyering and judging in some other (usually rhetorical) way. Arguments from "principle," for example, end by suggesting that all sorts of wonderful things will automatically flow from proper reflection upon the ideal of equal concern and respect. See R. Dworkin, supra note 11 . Civic republicans appeal to rather imprecise notions of "virtue" and "community" for salvation, apparently attempting thereby to deny, transcend, or delegitimate realworld political strife. See Kahn, Community in Contemporary Constitutional Theory, 99 Y ALE L.J. 1, 28-43 (1989) (discussing republican theorists); see also Mensch \& Freeman, supra note 63 (noting weakness of political vision). Other theorists, while recognizing the link between constitutional law and constitutional politics, attempt to explain their interaction by somewhat mystical references to "We the People." E.g., Ackerman, The Storrs Lectures: Discovering the Constitution, 93 YALE L.J. 1013 (1984); see Kahn, supra, at 18-28 (discussing Ackerman).

Curiously, even those who start from the assumption that constitutional arguments must inevitably be complex and varied still seem to be concerned with subsuming them all within a larger, more "coherent" structure. Richard Fallon, for example, concludes his survey of the various types of constitutional argument by suggesting that they all are subject, or should be subject, to some more or less definitive form of ranking. Fallon, A Constructivist Coherence Theary of Constitutional Interpretation, 100 HaRv. L. REv. 1189 (1987). Theorists like Laurence Tribe, whose viewpoint Fallon aptly describes as "open-systemed," id. at 1223-27, apparently seek consistency in the form of consistently desirable results. Moreover, by appealing to values "we" already share as the purported basis for their constitutional outcomes, L. TRIBE, Constirutional Choices (1985), they beg the question of what all the shouting is about: if "we" already agree on some issue, why is it still being fought about in our politics and on the Court? Finally, and most oddly, Critical Legal Scholars would seem to buy into Scalia's premise most thoroughly of all. See M. TushNeT, supra note 1 (highest goal of theory, apparently, must be absolute consistency; any theory that is inconsistent is a theory that is no good). But see Coons, Consistency, 75 CAlrf. L. REv. 59, 113 (1987) ("it is an offense against truth to pretend more order than this world allows."); see also Carter, supra note 2 (cautioning against obsessions with perfection).

The real dilemma facing progressive constitutional scholars was probably captured best not by an academician, but by a thoughtful progressive litigator:

In John Hart Ely's book Democracy and Distrust, he says that courts should not intervene except to correct some major dysfunction of the democratic process. I agree. Sometimes, in a brief, I cite Ely's book. Yet in real life, I throw Ely out the window for the right case. Clean up a union, reform an asylum, second-guess a pension fund, target housing aid to the poor ... or follow. Ely's theory? It's so clear in the books, but so hard, with the client out in your lobby.

Geoghegan, Warren Court Children: The Angst of an Aging Activist, New Republic, May 19, 1986, at 17-22 (May 19, 1986). Ironically, scholars may be taking this dilemma more lightly than the activist does, as he conscientiously attempts to fashion an existential, rather than merely logical, response to it. He tries to find a way of living conscientiously within this tension. 
nerable to all the criticisms formalism always is, provides a valuable starting point for a consideration of the cultural aspects of constitutional theory. But to use it as a starting point first requires considering briefly why so many scholars think it is such a clear dead-end.

\section{A. Cultural Sources of Academic Thought}

The distinguishing features of Justice Scalia's formalism are two: (1) it is a system; (2) it is a system selected for plainly pragmatic reasons. It represents an intentional effort to diminish the role of discretion and personality in the judicial enterprise. To say that it will not work perfectly is unnecessary; to say that it cannot work at all clearly is untrue. Indeed, even progressive scholars did not always look at constitutional literalism with today's contempt and disbelief, for what Justice Scalia's textualism first recalls is Scalia's textualist predecessor, Justice Hugo Black. To be sure, analogies between the two textualist Justices are easily overdrawn: not every brand of literalism automatically becomes constitutional "absolutism." But if the Scalia-Black comparison would superficially appear to invite "same church, different pew" analyses, why is there in academic circles such a tendency to remember Hugo Black with fondness, ${ }^{236}$ and such a seeming willingness to write Scalia off as a nefarious ideologue? There are sound reasons to suspect that the differing perceptions of the two men are connected as closely to changes in scholars' expectations of the Court as they are to differences in the two Justices' approaches.

A host of sociological, political, generational, and biographical factors only partially explored ${ }^{237}$-the displacement of would-be Ph.D's in the 1970 's, the political marginalization of would-be reformers, the sheer growth in law teaching jobs-have surely played a part in the "academicization" of law school culture during the past twenty years.

236. Sie, e.g., J. Magee, Mr. Justice Black: Absolutist on the Court (1979) (Black as leading defender of individual liberties); Hugo Br.ACK AND the Supreme Court (R. Strickland ed. 1967). But spe M. Silverstein, Constitutional Fatths: Felix Frankfurter, Hugo Black, and the Process of Judicial Decision-making (1984) (Frankfurter and Black not much different).

237. See, e.g., Binder, On Critical Legal Studies as Guerrilla Warfare, 76 GEo. L.J. 1, 34 (1987) ("critical legal studies is not an oppressed people's movement."); Sandalow, The Distrust of Politics, 56 N.Y.U. L. REv. 446 (1981) (liberal theorists seek to expand Court's role because they dislike results obtained through political process). No doubt because their views are more controversial, Critical Legal Scholars have been subjected to more of this sociological commentary than liberal theorists have. See Binder, supra. In addition, however, more of this type of commentary is available concerning them because they are more self-conscious concerning the scurces of their own ideas. See Schlegel, Notes Tou'ard an Intimate, Opinionated, and Affectionate History of the Conference on Critical Legal Studies, 36 STAN. L. REv. 391 (1984). Moreover, many Critical Scholars would contend that it is precisely their intention to speak idealistically about long-term possibilities, instead of worrying about short-term progress. Binder, Bejond Criticism, 55 U. CHL. L. REv. 888 (1988).

Liberal theorists, in contrast, usually do mean to speak to contemporary problems, and often find themselves accused of being elitist for being so interested in the courts. By and large, liberal theorists fecl uncomfortable being labelled elitist and uncomfortable about denying it. Normally, therefore, the charge simply is ignored, which of course leaves the liberals open to its constant repetition. 
During that period, progressive scholars of liberal and radical stripe have battled mightily with each other, and amongst themselves, intentionally creating a new and rarefied culture for the discussion of constitutional theory - a culture in which it has been considered open to debate whether law is "possible,"238 and in which the test of constitutional results has increasingly become their acceptability within limited or specialized circles. ${ }^{239}$ At the same time, a great deal of constitutional scholarship proceeded as though a large variety of non-textualist constitutional outcomes not only were desirable, but were also politically realistic to expect. This same culture also developed its own perceptual norms, tending to shape the world-view of its members just as Antonin Scalia's special cultural identity has shaped his. Thus, the attraction of spinning out ever more ingenious notions of how expansive interpretation could be justified and accomplished gradually excluded from the discussion whether effecting such expansive visions through adjudication was, or should be, anyone's first choice. Just to ask whether the Constitution really was so "perfect" was to risk being branded a conservative. ${ }^{240}$ But even as this culture became more and more vibrant within the legal academy-as scholars and interest groups ever more forcefully urged the Court to expand non-textual constitutional and statutory rights-the Court itself came more and

238. Fiss, Conventionalism, 58 S. CAL. L. Rev. 177, 189 (1985); see INTERPRETING LAW AND Literature: A Hermeneutic ReAder, supra note 63 . The hermeneutical excursion has been a particularly questionable one for progressive-minded scholars to have become engaged in. Politically speaking, the hermeneutics and interpretation controversies would really seem to represent the creation of a kind of Legal Process School for the 1980's. Like the original Legal Process Theorists, hermeneuticians turn discussions of law away from issues of politics and justice and toward arid questions concerning the competence of the materials through which law is made: legal institutions in the 1950's, legal language in the 1980's.

If there is a political point to all the hermeneutical discussions, it presumably has something to do with showing that language inevitably involves "discourses of power." It is difficult to see how anyone could doubt this, however, even without the benefit of the latest deconstructive semiotic training. Women and minorities, among others, have known for some time that power is encoded in language (and vice versa), and they learned this without elaborate studies of esoteric French and German theorists. See E. Genovese, Roll, Jordan, Roll: The World The Slaves Made (1975); C. GilliGAN, IN A DIFFERENT VOICE (1982). A final oddity of the hermeneutics phenomenon concerns the perception that the whole discussion is somehow novel or creative. In fact, of course, it is doubly derivative: first from Europe, second from the Department of English. Similar observations have been made about overly-elaborate "proofs" that we live in a rather indeterminate world. See generally Solum, On The Indeterminacy Crisis: Critiquing Critical Dogma, 54 U. CHI. L. Rev. 462, 503 (1987) (indeterminacy thesis is not particularly helpful in effort to construct "progressive and humane social order").

239. See Kahn, supra note 235, at 3 (contemporary theorists "no longer try to bring reason to will through argument directed at the general populace;" are increasingly concerned with developing a law-validating "community" whose membership will inevitably be severely restricted).

240. On the tendency toward constitutional "perfectionism," see Carter, supra note 2, at 831-40. The original anti-perfectionist, of course, was Henry P. Monaghan, whose own originalist tendencies made the charge of conservatism somewhat apt. See Monaghan, Our Perfect Constitution, 56 N.Y.U. L. REv. 353 (1981). Recently, it has become less unfashionable to make similar points, if from a rather different political perspective. See A Less than Perfect Union: Alternative PerspecTIVES ON THE U.S. ConSTITUTION (J. Lobel ed. 1988) (advocating substitution of historical and materialist analysis for idealism seen to characterize much current discussion). 
more to be composed of individuals who would not have taken it even as far as it had gone.

During the same period, "textualism," which had liberal connotations in the era of Hugo Black, increasingly assumed conservative hues. A mode of constitutional interpretation once seen as merely idiosyncratic came to be viewed in many quarters as inherently reactionary. In a sense it was-but only so long as one's view of politics did not extend beyond adjudication. Even as progressive scholars stretched the traditional forms of scholarship, importing a healthier sense of law's inescapable political dimension into their analyses, their conceptions of politics seemed to become increasingly fixated upon realizing their agendas through succeeding volumes of the U.S. Reports. They thereby unreflectively reinforced in practice precisely the same distinction between law and politics many of them said they were attacking, as they limited their scholarly attentions to the manipulation of appellate cases with all the passionate devotion of Christopher Columbus Langdell. ${ }^{241}$

But while progressive scholars concentrated their energies on bringing a "higher" politics into constitutional law through subtle and ambitious theories of interpretation, the practical political Right took constitutional law into ordinary politics instead, ultimately triumphing where Left and liberal scholars seemingly least expected-on the Supreme Court of the United States. Progressive scholars, obsessed with a desire to see their own hopes realized through prompt judicial action, consistently failed to exercise the same sophistication they demonstrated in advancing their own theories to accommodating those theories to this ever more apparent fact. ${ }^{242}$ The notion that these developments were strictly academic-cultural was confirmed, moreover, by another curious aspect of their timing. The progressive academy moved more and more toward expansive theories of constitutional interpretation precisely at the same time that front-line progressive advocates were turning ever more frantically toward factual, technical, and statutory arguments in order to win their cases before a hostile

241. The use of the term "New Langdells" is not meant to invoke Joan Williams, Critical Legal Studtes: The Death of Transcendence and the Rise of the New Langdells, 62 N.Y.U. L. REv. 429 (1987), who uses a similar phrase to suggest that Critical Legal Studies is "attempting a project as ambitious at Langdell's- to reinterpret law and legal education in the context of the most prestigious and authoritative intellectual currents available." Id. at 430 . In her own way, Williams is correct, of course, although one may fairly wonder whether the "prestige" attached to particular ideas is a valid reason for using them. Such strong words regarding the left Langdellians are not intended to suggest that Left Langdellianism has been without its positive effects in political, as well as intellectual terms. At their best, the expansive visions articulated in elite legal scholarship over the past two decades helped consolidate the larger public's shift toward more open views on a variety of "social issues," and possibly kept alive important visions for brighter days. Even at their worst, these largely intramural scholarly debates were more ineffectual than harmful, except insofar as the New Scholarship served to enrage and activate the Right.

242. On the changing complexion of those courts at a lower level, see H. Schwartz, Packing the Courts: The Conservative Campaign to Rewrite the Constitution (1988). For a notable exception to the charge made in the text, see L. Tribe, GoD Save This Honorable CourT (1985). 
Burger Court-or to keep them out of it altogether. ${ }^{243}$ In short, the sophistication gained at a "higher" level in 1980's legal scholarship was unaccompanied by-perhaps purchased only through a lack of-sophistication at a lower one. And this failure was made only more ironic by the fact that it was the central aspiration of so many of these progressive scholars to speak constructively to issues of general concern. Busy asserting in a thousand ways that all law was political, they somehow then left the politics out.

This profound misjudgment was not confined simply to misreadings of the external social world. An important additional aspect of it concerned the scope of constitutional theory itself, and thus arose on the scholars' intellectual home-turf. There long were clues in the constitutional developments of the Burger era that the progressive scholars' efforts were excessively compartmentalized. Despite a flood of books, treatises, and law review articles on every conceivable constitutional subject, until recently the Court's criminal procedure decisions have attracted remarkably little scholarly attention at the level of constitutional theory, ${ }^{244}$ apart from occasional comments by those who practice in the substantive doctrinal area, usually in specialized law reviews. ${ }^{245} \mathrm{Had}$ the theorists deigned to consider more closely this less-than-intellectually-compelling field, they would

243. For the best front-line discussion of this issue, see Geoghegan, supra note 235 , at 20-21 ("There are a few straight-out liberals left on the bench, but they always want you to settle. . . They know, and you know, it is all over if the other side goes up on appeal. You try to tell the client, "The worst thing we can do is win." ").

244. Again, a partial exception is L. TRIBE, AMERICAN Constiturional Law (2d ed. 1988), in which criminal procedure "is considered only in conjunction with other topics rather than as a unified and complete whole." Id. at vii n.1. The "other topics" generally concern such other issues as First Amendment rights, equal protection, and presidential powers and/or immunities. Another exception is Aleinikoff, supra note 7.

Wasserstrom and Seidman, in addition to noting this omission, see supra note 9, have also attempted to remedy it, searching for a "context-based theory of the Fourth Amendment," Wasserstrom and Seidman, supra note 9, at 103-12, which will allow lawyers to develop a "constitutional rhetoric" for Fourth Amendment cases "that is both powerful and true," id. at 106. Skeptical about the possibility or desirability of reconciling Fourth Amendment interests to the new "republican program," $i d$. at 110 , they advocate a combination of "positivism and imagination," $i d$. at 103, which they hope will improve "the quality of Fourth Amendment discourse," $i d$. at 105. Realistically assuming that absolute rules in such an area probably are "doomed," $i d$. at 107, they opt for a context-shifting discourse, based upon republicanism's insights, which "requires us to appreciate the degree to which our preferences change in different settings so as to deepen our sense of what it is we want," $i d$. at 110 . In the end, the vagueness of this "theory" only serves to illustrate the futility of striving for a comprehensive adjudicative formula. For Wasserstrom and Seidman themselves, "the legitimacy of constitutional review ultimately rests on how the practice is used," and debate about it will always be "inconclusive." Id. at 112 .

245. See, e.g., Maclin, Constructing Fourth Amendment Principles from the Governmental Perspective: Whose Amendment Is It, Anyway?, 25 AM. CRIM. L. Rev. 669 (1988); see also Kamisar, Does (Did) (Should) the Exclusionary Rule Rest on a "Principled Basis" Rather Than an "Empirical Proposition"?, 16 CReighton L. Rev. 565 (1983). To be sure, one reason why constitutional scholars have neglected criminal procedure may be that the scholars who "buried" it during the early Burger years ironically did too superb a job. See Amsterdam, Perspectives on the Fourth Amendment, 58 Minn. L. Rev. 349 (1974); Schrock \& Welsh, Up from Calandra: The Exclusionary Rule as a Constitutional Requirement, 59 MINN. L. REv. 251 (1974). After those extraordinary performances, subsequent scholars may have felt, quite appropriately, too depressed to continue looking at the field. 
long have been on notice that outcome-oriented departures from formalist norms, which they so ably promoted regarding other "agenda" items, held dangers as well as opportunities. Understandably lacking any concrete agenda in this area, progressive scholars never seriously attempted to integrate the lessons of the Burger era criminal procedure "balancing" into their larger theories. Thus their choice of subject matter inadvertently conceded the standard conservative charge that their scholarly concerns were politically rather than intellectually driven. Yet, in truth, the final irony is just the opposite: Liberal "grand theory," so frequently accused of being too politically and intellectually grandiose, suffered in important ways for not having been either politically or intellectually "grand" enough.

\section{B. Scalia, Scholarship, and the New Supreme Court}

At this point re-enter Justice Scalia and his textualism, stage (far) right. If constitutional scholarship requires reconstructive surgery after its collision with the Reagan-Rehnquist Court, it may make sense to begin this shift in emphasis by tentatively considering the issues raised, and lessons taught, by the application of Justice Scalia's methods to the field scholars previously neglected the most. The implications for the immediate future of criminal procedure doctrine are easily disposed of: Because the Warren Court changed so much of criminal procedure law so quickly, and the Burger Court then added so many more trees to the precedential thicket, they both tended to deprive the textualists of their text. Scalia's contribution, over the coming years, may be to remind them of it, as his obsessive semanticism at least partially undoes the separation between text and policy that the Burger Court accomplished. The results of his methods may not be a great deal more "liberal" than the decisions which preceded him. On the other hand, however, it also is safe to assume that Scalia's version of constitutional criminal procedure is unlikely to prove much worse. Reading cases for their "rules" is at least as likely to stop as to support a rightward "policy" drift.

Moreover, to say that mainstream constitutional theorists have largely neglected questions of constitutional criminal procedure in the articulation of their theories is not to say that the theories they have articulated lack implications for constitutional criminal procedure cases. In some respects, those theories apply directly: Theories concerning the interpretation of the Fourteenth Amendment's due process clause apply, of course, in almost identical fashion to the interpretation of the same language in the Fifth Amendment. Nevertheless, because the constitutional text at issue in criminal procedure cases is on the whole so much more explicit than the provisions with which the theorists have traditionally concerned themselves, the opportunities for divergence are greater than the opportunities for trans- 
plantation. Precisely because the Court has in recent decades invested such a great proportion of its resources in the interpretation of the criminal procedure clauses, the role of precedent-and the relevance of stare decisis-to the framing of constitutional theory may also be more central in this area. ${ }^{246}$

Several conclusions flow from these distinctions. First, with respect to criminal procedure, the dichotomy between interpretivists and non-interpretivists makes less sense. Just as we are "all legal realists now," too, in constitutional criminal procedure, are we all more or less interpretivists as well. We are as unlikely to make up genuinely new criminal procedure "rights" as the present Court is likely to recognize them. Moreover, because the adversarial, accusatory structure of the criminal justice process is so long-established in "unwritten" Anglo-American tradition, the basic existence of some "unwritten constitution" is not a disputed issue. ${ }^{248}$ To the extent that circumstances may require more open-ended interpretation, most of the serious controversies were sketched out-if not entirely settled-long ago in the course of the "incorporation" controversy concerning "fundamental fairness."

On the other hand, because so much more by way of background may be taken for granted in the criminal procedure area, and because that area is the subject of such intense interest on the part of the general public, "communitarian" approaches to the Constitution-whether Sanford Levinson's anti-hierarchical "protestantists," or Mark Tushnet's constitutional "anti-formalists"248 _assume greater relevance in criminal procedure than they might assume elsewhere. But that hardly means these are a force for good: a "good faith" exception to the exclusionary rule, allowing every officer to "interpret" the Fourth Amendment, is delightfully anti-hierarchical, after all. Moreover, organic communities, for which Critical scholars often argue, ${ }^{250}$ and special-interest-transcending "civic

246. In addition, certain special rules of textual interpretation-the "rule of lenity" in construing criminal statutes, for example-must also necessarily affect the formation of constitutional theories relating to the criminal procedure clauses. Plainly, such a rule affects (or may affect) interpretation of constitutional text as well.

247. Singer, Review Essay, 76 Calif. L. Rev, 465, 467 (1988) (reviewing L. Kalman, Legal REALISM AT YALE, 1927-1960 (1986)).

248. See also Schauer, Easy Cases, supra note 9, at 419 (in order to understand constitutional provisions relating to criminal procedure, "one must understand what a trial is").

249. See Tushnet, Anti-Fornalism in Recent Constitutional Theory, 83 MICH. L. REv. 1502 (1985).

250. Gabel, The Phenomenology of Rights-Constiousness and the Pact of the Withdrawn Selves, 62 Tex. L. REv. 1563 (1984). To be sure, Critical Scholars have not been monolithic on this point. Some have plainly recognized a special need for rights against the community in certain situations. See R. Unger, The Critical Legal Studies Movement 84-85 (1986) (possible need for "bright line" rules to protect individual "immunity rights"); see also R. UNGER, FALSE NECESSTTY: ANTINecessitarian Social Theory in the Service of Radical Democracy 524-30 (1987) (elaboration of "immunity rights" thesis). The Movement does have a history of being criticized, however, for having been slow to acknowledge the extent to which legal "rights" can concretely aid the socially disfavored. Cf. Symposium: Minority Critiques of the Critical Legal Studies Movement, 22 HaRv. C.R.-C.L. L. REv. 323 (1987) (early CLS work tended to slight minority experience 
virtue" theories ${ }^{251}$ operate in criminal procedure as particularly stark and visible forces against the basically counter-community purpose of the Bill of Rights. The central question in this area concerns how and whether the Court should defer to the exceptionally clearly expressed constitutional interpretations of the real-world, anti-crime "community," which already reacts to criminal procedure in a decidedly organic, visceral, and specialinterest-transcending way. Although the positivist approach to constitutional interpretation has been criticized extensively in the civil due process context, when applied to criminal procedure cases it produces substantial dividends. Most of the basic "rights" at issue in criminal procedure cases, after all, are positively created (or solidly part of criminal procedure's "unwritten constitution"), at least in general terms.

The tension between timeless text, non-textual principles, current "community" views, and positivist interpretation changes complexion, to be sure, when the vague principles of the criminal procedure clauses are weighed against duly-authorized "community"-passed statutes, as Justice Scalia's opinion in the juvenile execution case so clearly shows. ${ }^{252}$ The question then becomes more like those with which constitutional theorists are familiar: How and when can one use a relatively unclear Constitution to set aside a clear expression of current community will? Still, except in novel or limited circumstances, such direct confrontations between statutes and the Constitution have so far been comparatively rare. In criminal procedure, the more typical case involves a confrontation between a constitutional "principle" and an ad hoc police action or trial court ruling. Consequently, qualified acceptance, if not warm embrace, of positivist analysis and its dubious formalist assumptions may be in order. As a practical matter, it may take us somewhat further-and with greater credibility-in constitutional criminal procedure than in other constitutional arenas, even if it does not solve every problem.

Yet any decision by liberal (or Critical) theorists to adopt a form of positivism with respect to criminal procedure theory in response to such considerations wreaks fundamental structural damage on any and all attempts to generate all-encompassing nontextual theories, which might seem attractive elsewhere, and which have been so all-consuming. Focusing on how the Constitution's broad ambiguities can be used to create a more just and equal society, or to expand nontextual zones of privacy,

through cavalier treatment of legal rights); Responses to the Minority Critiques of the Critical Legal Sludies Moz'rment, 23 HARV. G.R.-C.L. L. REv. 293 (1988) (various critical legal scholars issue clarifications and express regrets).

251. See generally Symposium: The Republican Civic Tradition, 97 YALE L.J. 1493 (1988). Remarkably, in accordance with their Langdellian tendencies, even when liberal theorists attempt to "revive" our politics they instinctively seem to look-of all places!-to the courts. See Michelman, Traces of Self-Gotemment, 100 HaRv. L. REv. 4, 74 (1986).

252. See Stanford v. Kentucky, 109 S. Ct. 2969 (1989). Professor Sherry has similarly noted that Justice O'Connor's "obvious hostility to the rights of criminal defendants" may be explained by the fact that O'Connor has a "communitarian" perspective. Sherry, supra note 7, at 604. 
most of the leading theories usually concern expansive appeals to deeper nontextual "principle," suggesting that if we dig deeply enough into the constitutional culture we will find the theorist's hopes to be beliefs our culture already holds. ${ }^{253}$ In the process of constructing grand liberating theories, theorists have, paradoxically, also tended to slight the principles the Constitution does in fact codify-real principles many Americans may not hold, but with which they happen to be legally stuck.

The ultimate question, therefore, is whether a more nuanced-even internally contradictory-approach to constitutional interpretation would make more practical sense than it has recently been fashionable to admit. If so, the culturally powerful formalism Justice Scalia applies should surely be at least one part of the mix. As Frederick Schauer has noted, a picture of the Constitution as "text and rule" is disappointing and unattractive: "Nor is it a picture of a constitution that enables and empowers. Instead it is a picture of a constitution that disables and impedes." 254 It impedes not just the state as against the individual, but state activity for the individual as well. The harsh reality, however, is that the new Court will generally impede more positive efforts anyway, as its recent decisions on affirmative action, ${ }^{2 \mathrm{25}}$ if nothing else, make clear. The real question is how it will go about doing so.

In coming years, the practical emphasis will not be on "enabling and empowering" through the Constitution, but on "disabling and impeding" efforts to undo the gains that have been made. The text and a rule-oriented reading of precedent plainly serve as readily available constraints, and if accepting a somewhat narrow textualism in interpretation is the price of obtaining a rule-oriented approach to precedent, many would feel that under present circumstances the bargain is less than Faustian. Scalia's semantic approach to the Constitution's text may be absurdly acontextual, but "evaluating ruleness entails evaluating the selective virtues of acontextuality." ${ }^{286}$ For the moment, the political context of constitutional adjudication is only too clear, and acontextual textual interpretation, conscientiously applied, ironically produces certain desirable results-if only because the text just happens to support them. It is therefore not surprising that we have already seen a revival of interest among constitutional theorists in viewing the Constitution as "hard law."257

Focusing on the occasional practical benefits of Scalia's approach to criminal procedure, or on criminal procedure generally, also has other advantages for the grander enterprise of constitutional analysis. Thinking

253. See L. TRIBE, supra note 235.

254. Schauer, The Constitution as Text and Rule, 29 WM. \& MARY L. Rev. 41, 49 (1987).

255. See City of Richmond v. J.A. Croson Co., 109 S. Ct. 706 (1989).

256. Schauer, Rules, The Rule of Law, and the Constitution, 6 Const. Commentary 113, 285

(1989) (contribution to symposium titled The Constitution as Hard Law).

257. Id. 
more about criminal procedure might cause scholars to shift their emphasis away from merely developing abstract sources for decisions they desire and toward-or rather back toward-a more immediate concern with how the Court should best articulate the results it reaches. A practically oriented constitutional theory might be forced to contemplate the idea of phrasing constitutional decisions in different ways depending not just upon the social goals in question, or the textual passage under review, but upon the particular constitutional audience to be addressed: old-time theories turning upon the social subject matter and who one thought was attending the "vital national seminar"258 on any given day. Submitting constitutional adjudication once again to this type of Holmesian "cynical acid" test might help keep the scholarly enterprise more focused on the ineluctably political, as well as philosophical and hermeneutical, aspects of judicial review than it recently has been. Thus, if Justice Scalia's extremely rigid jurisprudence teaches us anything, it should probably be that jurisprudential rigidity of any sort is inappropriate. If his pragmatic approach to deriving jurisprudential theory teaches anything, it should probably be that excessively "theoretical" theorizing may be as much a cultural liability as a useful gift. If the cultural and biographical origins of Scalia's ideas seem unusually apparent, perhaps they should teach us to evaluate our own in a similar light-not only as "a bad man would," but as a good anthropologist might.

\section{CONCLUSION}

With respect to the implications of Justice Scalia's methodology for other areas of the law, his opinion in the drug-testing cases may be the most significant of those reviewed. There, as in most areas with which constitutional scholarship has recently been concerned, his usual methods do not produce automatic answers. Yet his reliance upon the technique of converting what many of his colleagues see as "policy" issues into more legalistic procedural ones suggests a significant departure from much recent Supreme Court behavior, and not merely in criminal procedure law. Factually solid cases-or even cases with definitive trial court factual rulings-might be relatively more protected from Supreme Court reversal with Scalia on the Court than they would be without him. To the extent that new or existing "liberal" decisions are phrased in terms of traditional decisional principles-fidelity to text, consistency with precedent, with all the t's crossed and all the i's dotted-those who fear Scalia's politics may have less to be concerned about than they suppose.

Moreover, if the Court has become dysfunctional in criminal procedure

258. Rostow, The Democratic Character of Judicial Review, 66 HARv. L. Rev. 193, 208 (1952). One good example of how this might be done is Schuck, The Thickest Thicket: Partisan Gerrynanlering and Judicial Regulation of Politics, 87 Colum. L. Rev. 1325 (1987). 
through its overly enthusiastic embrace of non-textual "policy," far more areas of the law have been damaged by the recent Court's neglect of the Supreme Court's own traditions and procedures: its sudden and unprincipled self-reversal concerning "independent and adequate state grounds," 259 its unpredictable spasms of ideological haste leading to the resolution of important cases before they have been fully briefed, ${ }^{260}$ its docketing of cases which do not, under governing criteria, deserve plenary review. ${ }^{281}$ One may fairly speculate that the apparent adherence by Scalia to a conscientiously essentialist notion of what a "court" does might also constrain him when the Court is deciding which cases to accept.

In the end, therefore, the larger practical importance of Scalia's approach lies most likely in the details. His refusal to discuss probable cause in Hicks because it was not raised, his refusal to reverse the lowa court outright in Coy because it had not reviewed the case for the possibility of "harmless error," his use of burden of proof rules to narrow the scope of "balancing" in the Customs Agents Case, his search for a broad principle of double jeopardy in Thomas - all suggest that in certain limited but important circumstances Scalia could be a positive, as well as positivist, force on the Court, helping to restore a sense that the Court itself must also be guided by "the rule of law." Even if, by the very nature of the caseacceptance process, these speculations will never be confirmed, one may still take comfort from the fact that in the analogous religious context catechetical analysis is honored more, not less, behind the drapes of the confessional. As Justice Scalia himself has noted,

$[O]$ ne of the functions of procedure is to limit power-not just the power to be unfair, but the power to act in a political mode, or the power to act at all. Such limitation is sometimes an incidental result of pursuing other functions, such as efficiency or fairness; but it may be an end in itself. ${ }^{262}$

After nearly twenty years of "rootless activism," political direction, it would indeed be a change for the better if such limi-

259. Michigan v. Long, 463 U.S. 1032 (1983) (requiring state courts to state plainly their reliance upon independent and adequate state grounds).

260. See, e.g., Snepp v. United States, 444 U.S. 507 (1980) (major First Amendment case decided without briefing or oral argument).

261. See S. Estreicher \& J. Sexton, Redefining the Supreme Court's Role: A Theory of Managing the Federal Judicial Process (1986) (Supreme Court reviews many cases it should not); see also Florida v. Myers, 466 U.S. 380 , 386 (1984) (Stevens, J., dissenting) (recapitulating, with annoyance, Burger Court's extensive use of its supposedly precious time to reinstate individual criminal convictions in cases without precedential value). It has been extensively noted in the media that the Court appears to have been trying to select its cases somewhat more carefully in the last two years-or, at least, trying to select fewer of them.

262. Scalia, Vermont Yankee: The APA, The D.C. Circuit, and the Supreme Court, 1978 SuP. CT. Rev. 345, 404-05.

263. Blasi, The Rootless Activism of the Burger Court, in The Burger Court: The CounterRevolution That Wasn't 198 (V. Blasi ed. 1983). 
tations were suddenly thought once again also to "limit the power" of the Court.

With respect to criminal procedure itself, the potential benefits of Justice Scalia's severe literalism are not limited to those suggested in the opinions reviewed here. Significant changes in criminal procedure would be wrought, for example, if a literalist Court gave the same broad meaning to the adjective "secure" in the Fourth Amendment that it gives to the noun form of the same word in "national security" cases, ${ }^{264}$ or if "probable cause" were actually taken to mean "more probable than not." A doctrinal revolution would result if such vague notions as "the totality of the circumstances"26s were subjected to a jurisprudence of "text and rule"-something that Justice Scalia has already hinted he just might want to do. ${ }^{286}$ And, broadening the subject to other constitutional arenas once again, suppose that we awoke one morning to discover that the Eleventh Amendment, after all, actually does mean only what it says. Profoundly destabilizing, to be sure, and for that reason contrary to Scalia's rule-bound view of precedent, ${ }^{267}$ but a bonanza for civil rights litigants-and formalist to the core.

While legislative options are available for redressing the new Court's turn against broad conceptions of equality and justice in many areas of constitutional concern-abortion, the civil rights statutes, women's rights, and privacy-where there are organized (or organizable) constituencies with a direct interest in joining political and legislative battles, ${ }^{268}$ such options do not exist when it comes to criminal procedure. For the foresee-

264. See Haig v. Agee, 453 U.S. 280 (1981); Snepp v. United States, 444 U.S. 507 (1980); New York Times Co. v. United States, 403 U.S. 713, 719 (1971) (Black, J., concurring) ("The word 'security' is a broad, vague generality"). See generally Edgar \& Schmidt, Curtiss-Wright Comes Home: Expcutite Pau'er and National Security Secrecy, 21 HaRv. C.R.-C.L. L. Rev. 349 (1986) (tracing growth of national security rationale).

265. But see Illinois v. Gates, 462 U.S. 213 (1983) ("totality of the circumstances" test for probable cause).

266. "We certainly take, on certiorari, a number of Fourth Amendment cases in which the question seems to me of no more general interest than whether, in this particular fact situation, pattern 3,445 , the search and seizure was reasonable." Scalia, Rule of Law, supra note 27, at 1186 .

267. Welch v. Texas Dept. of Highways, 483 U.S. 468, 495-96 (1987) (Scalia, J., concurring) (indicating misgivings about Hans v. Louisiana, 134 U.S. 1 (1890)); Pennsylvania v. Union Gas Co., 109 S. Ct. 2273, 2296-99 (1989) (Scalia, J., concurring in part, dissenting in part) (reaffirming Hans because "orginal meaning" of text ambiguous).

268. Fortunately, it is clear that our politics, like our scholarship, has also functioned for twenty years in the afterglow of the Warren Court. Formerly marginal interests have had time to grow into powerful Washington institutions. Thus, if one consequence of a rise in textualism is to require Congress to write clearer laws, Congress has recently, and after some struggle, been able to do so-at least in certain important areas, like the scope of the Civil Rights statutes and the Voting Rights Act. Compare Grove City College v. Bell, 465 U.S. 555 (1984) and City of Mobile v. Bolden, 446 U.S. 55 (1980) w'th The Civil Rights Restoration Act, Pub. L. No. 100-259, 102 Stat. 28 (1988) and the Voting Rights Act Amendments of 1982, Pub. L. No. 97-205, 96 Stat. 131. The Court itself has recognized that the 1982 amendment to the Voting Rights Act was directed at reversing City of Mobile. Thornburg v. Gingles, 478 U.S. 30, 35 (1986). It will also almost surely now be easier to stop legislative attempts to curtail rights long-exercised because of Roe $\tau$. Wade than it would have been to build the political constituency necessary for lifting limitations on choice in the first place. 
able future, criminal procedure will continue to be an area where the Supreme Court plays a uniquely important role, and where a rigorous formalism may sometimes aid the cause of the unpopular and disfavored.

In the midst of a judicial sea-change of the sort we are undergoing, it is neither alarmist nor intellectually dishonest for scholars to consider adjusting their agenda in light of these new realities - and even less so for those scholars whose premise is that all law is political. It behooves them, if they think that, to act as astute politicians. The new Supreme Court presents most starkly the old Emersonian question: whether the drive to generate all-encompassing "grand theories" of constitutional interpretation has not taken on the flavor of an overly narrow "consistency"-a failing shared as well by those who Criticize other people's theories for being contradictory or incomplete, confirming as they do so the idea that consistency is the goal toward which everyone should strive.

Given the ethereal reaches in which much constitutional and legal theory now operate, even to raise such base tactical concerns is to risk seeming intellectually déclassé. Yet the current attraction of "grand theory" for constitutional scholars itself has a rather short history. ${ }^{269}$ Not so long ago respectable and thoughtful scholars were not ashamed frankly to discuss the potential "passive virtues," able in the Supreme Court's tactical repertoire, with an eye toward determining what the real Supreme Court should really do. It hardly seems more shameful now to consider what it should not do.

"Trashing" the new Court is easy and seductive-and irrelevant and unnecessary. There is no great mystery about what is going on. In current circumstances, even a return to a 1950's Bickelian concern for "prudence" would still leave scholars literally decades ahead of the current Supreme Court. ${ }^{272}$ And that part of Bickel's analysis which emphasizes temperamental prudence on the part of scholars seems more relevant now than ever. When happier days again return, we will do well to remember the painful lessons we are learning now.

Whether Critical Legal Studies, Borkean originalism, constitutional anti-formalism, or civic republicanism triumph or fade as governing aca-

269. M. TUSHNET, supra note 1, at 1-17.

270. A. Bickel, The Least Dangerous Branch 111-99 (1965).

271. See Gunther, The Subtle Vices of the Passive Virtues, 64 Colum. L. Rev. 1 (1964). Of course, for better or for worse, Gunther's fear that frank use of these "passive virtues" would harm the Court by overtly politicizing it in the public mind now seems somewhat out of date-or, rather, overtaken by events.

272. See Kronman, Alexander Bickel's Philosophy of Prudence, 94 YALE L.J. 1567 (1985) (Bickelian judge is one who moves warily and circumspectly). But see Purcell, Alexander Bickel and the Post-Realist Constitution, 11 HARv. C.R.-C.L. L. REv. 521, 554 (1976) (toward end of his life, "Bickel's primary goal shifted from achieving moral reform to ensuring social tranquility"); see also Ackerman, supra note 235, at 1014 (Bickel ended up as lead spokesperson for those who believe in judicial restraint). The challenge will be to prevent "prudence" from becoming an excuse for justifying doing nothing. R. NAGel, Constirutional Cultures (1989) (plain-speaking court would do less). 
demic theories, it remains clear that Americans still have considerable affection for the Constitution's venerable text. ${ }^{273}$ Wishful thinking about hypothetical "communities" and non-interpretive ideals have their strong attractions, to be sure, and it would impoverish the legal academy's intellectual life-not to mention this society's long-range possibilities-if they were to disappear. But wildly expansive theories of interpretation would still only be likely to produce consistently positive results "if angels were to govern men."274

Until the angels come, alas, dissonance and indeterminacy will inevitably be our lot. Those confident of their own salvation may comfortably await the angels' eventual descent in the eager certainty that they will then hear their God "speak." Judgment with greater trepidation may be wiser to seek guidance in more mundane reflections. That "good grey poet" Whitman was surely on to something when he made contradiction a sign of vitality and inner strength, rather than of defeat. More humble, if not less hopeful, in bright times as in dark, we will do well to remember the lessons taught by skepticism as well as those conveyed by faith.

273. Sep generally M. Kammen, A Machine That Would Go Of Itself: The ConstituTION IN AMERICAN CULTURE (1987) (charting and criticizing American tradition of venerating Constitution).

274. The Federalist No. 51, at 356 (J. Madison) (B. Wright ed. 1961).

275. R. Unger, KNowledge and Politics 295 (1975). 